\title{
FEDERAL PRICE CONTROL OF NATURAL GAS SOLD TO INTERSTATE PIPELINES
}

Consumers throughout the country buy natural gas that flows from a burner tip 1 after an interstate pipeline journey of hundreds of miles from producing fields. ${ }^{2}$ Local distributing companies sell this gas at rates that generally are subject to ceiling control by the consuming states. A large part of these end rates covers the wholesale purchase of gas from interstate pipelines ${ }^{3}$ at maximum rates set by the Federal Power Commission. The pipelines' rates in turn often include the cost of gas bought from big oil and gas companies, the "independent" or non-affiliated producers. ${ }^{4}$ No ceiling has been placed on these independents' prices.

During the last decade, however, a controversy has been brewing over whether the FPC has the power to extend maximum price control to independents' sales to interstate pipelines. Because its members have not been able to agree that they have such authority, the Commission has not yet sought to

1. In June, 1950 there were an estimated $12,700,000$ residential and $1,140,000$ commercial and industrial users of straight natural gas. There were also about $9,600,000$ users of manufactured and mixed (manufactured and natural) gas. SURvey of CURRENT Business S-26 (U. S. Dep't Comm., Oct. 1950).

There has been an increase of over fifty per cent in the number of straight natural gas consumers since 1946, when utilities supplied 8,700,000 customers in 34 states. Then nearly two-thirds of the total number, however, were in California, Ohio, Michigan, Pennsylvania, and Texas. Besides utility customers, some $3,500,000$ homes, mostly in rural areas, used bottled liquid petroleum gas in 1946. FPC, Docket No. G-580 Natural Gas INvestiGATION 398-9 (Smith-Wimberly Report 1948) (hereinafter cited as SMITH-WiMDERLY REP.).

Most of the domestic gas consumption is for cooking and to a lesser extent water henting, but the use of gas for space heating is growing rapidly. See SMTrH-WiMuERLY REP. 400-6; N.Y. Times, Oct. 8, 1950, § 3, p. 1, col. 4.

2. There are no figures on the number of domestic customers using natural gas that comes from other states. But approximately a third of the marketed production of natural gas is transmitted through pipelines in interstate commerce, see p. 1470 infra, and residential use accounts for about a third of utility sales, see note $126 \mathrm{infra}$.

For a recent map of the country's major natural gas pipelines see Hearings before Sibcommittee of Senate Comnittee on Interstate Commerce on S. 1498, 81st Cong., 1st Scss., facing 360 (1949).

3. There are no figures for the average price the distributing companies pay to pipelines for gas delivered at the city gates. In 1949 the Detroit wholesale rate was about 20 cents; New York's about 30 cents. See Hearings before Subcommittec of House Committee on Interstate Commerce on H.R. 79, 1758, and 982, 81st Cong., 1st Sess. 264-5 (1949).

For a graphic analysis of pipeline transmission costs at various load factors, see SurruWIMBERLY REP. 265.

4. While most of the interstate pipelines produce part of their gas requirements, they are buying an increasing share from independent producers. See pp. 1485-86 infra. The prices for these purchases vary widely. See note $100 \mathrm{infra}$. In the chief producing area of the southwest purchase prices averaged 4.65 cents per thousand cubic feet in 1947, see p. 1486, infra, or approximately 8 per cent of the average domestic rate. See note 192 infra. 
assert it. But the fear that the Commission might try to regulate them led gas producers, starting in 1947 , to ask Congress to write a hands-off policy into statute.

Meanwhile, in the face of a booming postwar demand for natural gas, there has been a sharp upswing in the prices paid by interstate pipelines in the important southwest producing region. Aroused at the prospect that unchecked increases will mean higher gas bills, ${ }^{5}$ spokesmen for consumers have argued that the FPC now has the power to regulate sales by independents to interstate pipelines. ${ }^{6}$

Consumer and producer interests clashed last spring over the Kerr bill which would have explicitly barred FPC jurisdiction over independents' sales. President Truman's veto, unchallenged by Congress, may now encourage the FPC to attempt to regulate the independents' prices.

Amidst all the clamor, however, except for brief congressional hearings and debate, ${ }^{7}$ there has been no study of the problem whether independents' sales to interstate pipelines should be regulated. ${ }^{8}$ Placing this issue in perspective requires first a consideration of existing government regulation of the natural gas industry.

There are three steps in supplying natural gas to its 14 million users. ${ }^{9}$ In the first step, production and gathering, gas is drawn from the earth, often along with oil.10 It is gathered in by a network of field pipes and processed to remove both nuisances and valuable by-products. ${ }^{11}$ MIuch of this gas is

5. See, for example, 96 CoNG. Rec. 4263 (Mar. 28, 1950) (remarks of Sen. Douglas of Illinois). Consumers' rates had dropped slightly from 1939 to 1947. Hcarings, sipra note 2 , at 362 .

6. See, for example, Hearings, supra note 2, at 457, 459, 460 (City Solicitor, Pittsburgh, $\mathrm{Pa}$.) ; Hearings, stipra note 3 , at 160 (City Council, Kansas City, 15o.); id. at 280 (National Institute of Municipal Law Officers).

7. Hearings, supra note 2; Hearings, stipra note 3; Supplemental Hearings before Subcomnittee of House Committce on Intersiate Commerce on $H . R .79,1758$, and 982, 81st Cong., 1st Sess. (1949). For the debates see 96 CoNG. Rec. 3406-4285 possin (Afar. $15-28,1950)$.

8. In 1945-6 the FPC conducted a detailed investigation of the competition of natural gas with other fuels. Surth-W IMrBerLy REP. 1-2. For the background of this study see note 248 infra. The Commission announced at the outset that it did not seek to expand its jurisdiction over independent producers. Sarrth-W marberly Rep. 165-6. In spite of this assurance the hearings became a forum for pipeline-producers angered by FPC regulation and independents fearful of it. At the end of its investigation the Commission issued two reports. Both gave considerable attention to the pipelines' case but scarcely any to the independents'. Nevertheless two Commissioners hinted that perhaps the independents should be regulated. FPC, Docket No. 6-580 Natural Gas Investication 158 (DraperOlds Report 1948) (hereinafter cited as Draper-Ozds Rap.). The other two Commissioners saw no need for this. SMIrth-Wnirerly Rep. 8 .

9. See note 1 supra.

10. DeGolyer (ed.), Elearents of the Petroleux Industry 433 (1940).

11. Natural gas contains liquid-forming components which, on condensing, cause trouble with pipeline meters and other equipment. Sarith-Wrasoenly REP. 92. Process- 
then used by the producers themselves as fuel in drilling and pumping operations. ${ }^{12}$ And much is sold to nearby industrial plants. ${ }^{13}$ All told, about a third of the total marketed production is consumed right in the field. ${ }^{14}$ The other two-thirds of the marketed gas moves into pipelines ${ }^{15}$ for the second big operation of the industry, long-distance transmission to consumers. About half this volume is consumed within the producing states themselves. ${ }^{10}$ Part of the total amount of pipeline gas-whether consumed inside or outside the producing states-is sold directly to individual industrial plants. ${ }^{17}$ The rest is passed on to distributing companies for the third operation of the gas business, resale through local mains to household, commercial and industrial users. ${ }^{18}$

In broad outline, there has developed within the natural gas industry and paralleling its tripartite structure, three separate sectors of government control: (1) production is controlled by the states; (2) intrastate transmission and local distribution are also regulated by the states; and (3) interstate transmission is regulated by the federal government through the FPC.

\section{Control of production}

State Regulation of the Natural Gas Industry

At the producing end of the natural gas industry, state regulation has been

ing the gas yields valuable natural gasoline and heavier hydrocarbons, and gets rid of water vapor and sulfur compounds. Id. at 89-101.

12. This "field use" accounts for about 23.5 per cent of natural gas consumption. Id. at 364.

13. About 11 per cent of marketed production, see note 14 infra, is used in the producing fields for the manufacture of carbon black, an ingredient of inks and rubber compounds. Id. at $365-7$.

14. Marketed production is gross production less gas returned to the reservoir, sec note 25 infra, and loss and waste. Smrth-Wimbercy REp. 105, Table 3. In 1946 this marketed production totalled about 4 trillion cubic feet. Ibid.; $i d$. at 360, Table 2 . Consumption in the field included 960 billion cubic feet for "field uses", see note 12 supra, and 478 billion cubic feet for the manufacture of carbon black, which is carried on chiefly in the producing fields. SMith-WrarberLy Rep. 365. Id. at 360, Table 2.

15. Smith-Wimberly Rep. 247, Table 2.

16. Ibid.

17. Reported statistics do not distinguish between the volume of gas sold direct to industry by pipelines and that sold by local distributing companies, nor between direct industrial sales made within the producing states and those made in other states.

Direct pipeline industrial sales are heavy in the southwest. In 1948, for example, the Interstate Nat. Gas Co. sold 74 billion cubic feet to industry and 47 to other utilities. FPC, Statistics of Nat. Gas Companies 1948, 109. Cities Service sold 56 billion to industry as against 114 billion to utilities. Id. at 104 .

Pipelines serving northern markets sell a smaller proportion of their gas direct to industry. In 1948 the Northern Natural Gas Co. sold 18 billion cubic feet to industry and 114 billion to utilities. Id. at 116. Texas Eastern Transmission Corp. sold none to industry and 118 billion cubic feet to utilities. Id. at 123 .

18. Residential and commercial use accounts for about one-third and industrial use for two-thirds of the natural gas marketed through pipelines. SMITH-WIMnERLY REp. 410. 
undertaken, and justified legally, as a conservation measure. ${ }^{10}$ A fourth of the country's gas is pooled in the ground with oil ${ }^{\mathbf{2 0}}$ and furnishes pressure which lifts this oil to the surface. ${ }^{21}$ In the absence of a market for this casinghead gas, it is frequently blown in the air or burned at the wellhead.2 As recently as 1945 a fifth of the country's total gas production was lost in this way." Alarmed both at the effect that this loss of a pressure source will have on ultimate oil recovery and at the waste of an ideal fuel, states have limited the oil output of wells producing an excessive amount of gas $^{24}$ and have forbidden the blowing of gas in the air. ${ }^{25}$

The pipelines' main gas supply comes, however, from dry gas fields where production is geared to the demand for gas rather than to the demand for oil. ${ }^{26}$ As in the oil fields, reckless exploitation was long encouraged by the

19. The most comprehensive surveys of the development of state production control of gas and oil are Amr. Bar Ass'n Sec. of Min. Law, Legar History of Conservutron of Oiz and Gas (1938), and Amr. Bar Ass'n Sec. of Min. Law, Conserwitio: of Oil AND GAS-A Legal History (1948). An excellent concise account of gas waste 15 years ago and state attempts to check it, is found in Ses. Doc. No. 92, Pr. 84-A, 70th Cong., 1st Sess. 86-110 (FTC Utility Corporations Rep. 1935).

20. SMrthi-W WMrberly Rep. 35.

21. Id. at 70-1.

22. Id. at 70 .

23. Id. at 114 .

24. E.g., Tex. Civ. Stat. Ann., art. 6008, §3(a) (Vernon 1949). See Adminisiration of Gas-Oil Ratio Limitations, INTERestate OIL Cosipact Q. Bull. 97 (Dee 1947). But restricting a producer's output in this way merely keeps more oil and gas in the common pool to be drained off by a neighbor. See Knowlton, The Protection of Correlalize Righis as a Linitation of Regulation of Oil-Gas Ratios, Interstate Orl Co:spact Q. Butr. 34, 35 (May 1948). The solution of the conflict between conservation and surface owners' property rights appears to lie in unit operation of the fields. Id. at 35. See p. 1474 infra.

25. In recent years the Texas Railroad Commission, for example, has prohibited the blowing of casinghead gas in a number of fields. See Hearings, supra note 2 , at 36-65.

Such a prohibition gives producers three choices:

(1) Shutting down their wells. See ALurray, Natural Gas Problems in Tcrrilory of Greatest Reserves, Axr. Gas As's's, Nat. Gas Dep't, Proceedings 10, 13 (1949).

(2) Pumping gas back into the oil reservoir to maintain pressure Repressuring and pressure maintenance of oil reservoirs are explained in Surrta-WWurderLy REP. 70-8. See also id. at 105 (table showing gas returned to formation).

(3) Selling casinghead gas to the pipelines, which are now absorbing such gas in increasing amounts. Bur. Mínes, MIInerals Yearbook 811 (1948). See also Duff, FourYear Natural Gas Program to Cost Nearly Two Billion, OrL \& Gss. J. 229 (Jan. 27, 1949); Weber, Huge Gas-Couscrzation Project Now in Initial Opcration Stage, Ort \& GAs J. 60 (July 8, 1948); Kayser, Flare Gas and Its Relation to Rescrics, Ass. Gss Ass's, Nat. Gas Dep'T ProceEdings 13, 14 (1948); Hearings, supra note 2, at 310.

26. The Hugoton field, extending from southwest Kansas across the Olshahoma panhandle into Texas, and the Panhandle field in northern Tevas, are the country's largest dry gas fields. Sarith-WIMrberly Rep. 40. 
rule of law holding that gas, like a wild animal, belonged to its captor. ${ }^{27}$ The rule of capture put the independent producer in a dilemma. If he chose not to produce gas immediately it was apt to be sucked from under his feet by a neighbor whose well tapped the reservoir extending under both their lands. ${ }^{28}$ To protect himself against this drainage the independent had to drill an offset well and bring up all the gas he could. ${ }^{29}$ Then he met the other horn of the dilemma. Unlike oil, gas could not feasibly be stored above ground, and could be transported from the field to market only through costly pipelines. ${ }^{80}$ Since initially the pipelines produced much of their gas requirements, ${ }^{31}$ they were under no pressure to buy from independents. ${ }^{32}$ Many producers, therefore, sold their gas at virtually giveaway prices to nearby carbon black plants, and some simply let the gas blow in the air, hoping in time to bring up oil. ${ }^{34}$

Producing states soon passed statutes forbidding physical waste of dry gas. ${ }^{\text {at }}$ And most of them have restricted the use of gas for the manufacture of carbon black. ${ }^{30}$ But enforcement of these prohibitions would close down wells of producers without pipeline connections and permit drainage from under their lands. The states have therefore sought to force the pipelines to take gas from the independents as well as from their own reserves. ${ }^{37}$

The earliest move was through statutes declaring the pipelines to be common purchasers who must buy gas without discriminating among producers. ${ }^{\mathfrak{d} g}$

27. See Hardwicke, The Rule of Capture and Its Implications as Applicd to Oil and Gas, 13 TEx. L. Rev. 391 (1935).

28. Nat'i Resources Committee, Energy Resources and Nat'i Policy 186 (1939). See also Oliver \& German, Changes Needed in Oil Ozenership Law, 30 OIL \& GAS J. 15 (Jul. 23, 1931).

29. Sen. Doc. No. 92, Pт. 84A, 70th Cong., 1st Sess. 181-2 (FTC Utility Corporations Rep. 1935).

30. Id. at $128-9$.

31. Id. at $160-4$.

32. See id. at 132, 184-195.

33. SMith-Wiarberdy Rep. 369.

34. Sen. Doc., supra note 29, at 88; Ars. Bar. Ass'n Sec. of Min. Law, Legal History of Conservation of Oil aNd Gas 136-7 (1938). Later the producers extracted the natural gasoline before letting the gas blow away. Ibid.

35. Amr. BAr Ass'N, op. cit. supra note 34, at 112 (Oklahoma 1905); id. at 269 (Texas $1899)$; $i d$. at 61 (Louisiana 1906).

36. E.g., LA. Acts 1922, No. 91, § 1-8, LA. Gen. Stat. ANN. $\S \S 4811-4818$ (Dart 1949). In 1941 Texas prohibited the use of "sour" gas for manufacturing carbon black unless the natural gasoline was taken out. Tex. Acrs 1941, p. 117, c. 91, §2, TEx. Crv. StuT., Art. 6008, \$ 7 (2) (Vernon 1949). See Smita-Wimberly Rep. 371.

37. For an excellent account of the conflict between the pipelines and the independent producers in Texas during the 'thirties, see AMr. BAr Ass'N SEc. of Min. LAw, LegnL History of Conservation OF OIL AND Gas 270-86 (1938).

38. Oklahoma was first in 1913. OkLn. Stat. Ann., tit. 52, § 23 (1937). Texas followed in 1931. Tex. Crv. Stat. AnN., art. 6049a, $\$ 8$ a (Vernon 1949). Recently Michigan enacted a common purchaser statute for gas pipelines. Mich. ANN. StAT. $\$ 13.138(27)$ (Rice Cum. Supp. 1949). 
These statutes, however, failed to define "discrimination," and did not establish any mechanism for determining when a pipeline was purchasing a fair share from any producer. Mioreover the constitutionality of such a statute has been in doubt. ${ }^{39}$

The states therefore adopted the additional device of prorationing: ${ }^{40}$ At periodic hearings before state commissions, purchasers of gas from a common pool make "nominations" of the amount they expect to buy during the ensuing period. In order to meet this "market demand," the commission then sets a production quota for the pool. This quota, in turn, is broken down into "allowables" for each well, determined according to complicated formulae that take into account such factors as acreage per well and flow pressure."1 Since this tactic necessarily limits the amount of gas a pipeline may produce from its own wells, the states hope to force the pipelines to meet their requirements by purchasing gas from independents. ${ }^{2}$

39. The Texas common purchaser statute, supra note 38, was held to violate the due process clause of the Fourteenth Amendment in Texoma Nat. Gas. Co. v. Railroad Comm'n, 59 F.2d 750, 753 (W.D. Tex. 1932) (no appeal taken). This led Texas to turn to the device of prorationing. See note 40 infra.

In the first case involving the enforcement of the OHlahoma statute, stipra note 38 , the Supreme Court dismissed the appeal because the judgment of the Ollahoms Supreme Court lacked finality. Republic Natural Gas Co. v. Oklahoma, 334 U.S. 62 (1948).

40. E.g., OrL. Stat. ANn., tit. 52, \$239 (1937); Tex. CIv. Stat. Axm., art. 6008, $\$ \S 10-20$, art 6049 d, $\$ \$ 4,6$ (Vernon 1949). Prorationing legislation is on the statute bools of 11 states. See Sarrth-IVIarberly Rep., chart facing 12S.

While oil prorationing has been practiced since the 'thirties, prosationing in the dry' gas fields has developed largely in the last decade. Kansas started prorationing in its part of the great Hugoton field in 1940. Asr. Bar Ass's Sec. of Mirs. Law, Cosservatron OF OIL AND GAS-A LEGAL HISTORY 176 (1948). Oklahoma began in the Hugoten field in 1945, id. at 404, and Texas in 1948. Texas Part of Hugoton Gas Field Put Under Connmission Proration, OIL \& GAS J. 57 (Sept. 30, 1948).

41. For an illustration of state gas prorationing see the explanation of Kansas and Oklahoma procedure in Dahlgren, The Hugoton Gas Field, Istrenstate Orc Coupact Q. BuLL. 203, 207-10 (June 1945).

Oil prorationing generally starts with a determination of a state-wide allowable which is then broken down among various fields and further subdivided among wells. See, for example, the discussion of Oklahoma procedure in Asr. BAs Ass's, op. cit. supra note 40, at 373-4. In their dry gas prorationing the states so far have been content to fix allow:ables separately for each field. The future may see a trend toward state-wide inter-pool allocation of production for dry gas as well as for oil. See MIurray, Nalural Gas Problems in the Territory of Greatest Rescries, Ass. Gas Ass's, Nat. Gas Dep't, Proceedmos 10,15 (1949).

For a discussion of the methods of allocating fractions of a field's quota to individual wells, see INTERSTATE Oil Cosrpact Q. Bulz. 66 (Dec. 1949).

42. See Thompson v. Consolidated Gas Utilities Corp., 300 U.S. 55 (1937), in which the Court upheld an injunction against enforcement of a prorationing order dirceted at a pipeline producing its own gas. But the Supreme Court of Texas has since upheld gas prorationing. Corzelius v. Harrell, 143 Tex. 509, 186 S.IW.2d 961 (1945).

A recent survey of regulatory practices in the dry gas fields is published in the IritenState Oil Compact Q. Bull. 61 (Dec. 1948). 
But these measures leave untouched another problem: the needless investment in wells and the dissipation of reservoir energy that results from allowing each surface owner to drill no matter how small his tract. ${ }^{43}$ In fact, both the common purchaser and proration statutes encourage owners to drill more than the optimum number of wells in order to get a larger share of the quota for the pool. For this problem well spacing statutes ${ }^{44}$ are only a partial solution.

Under spacing rules, unnecessary and improperly placed wells may still be drilled.45 Engineers therefore agree that maximum recovery at minimum cost can only be had by operating each reservoir as a unit. ${ }^{40}$ Several states have taken half steps in this direction, by allowing landowners to pool their surface interests into committee-run units for drilling purposes. ${ }^{47}$ And in 1945 Oklahoma adopted a statute providing for compulsory unitization of a common reservoir on the application of the owners of a majority of the surface acres. ${ }^{48}$ Gradually the ideal of pool unitization is making headway.

\section{Regulation of distribution and intrastate transmission}

At the distributing end of the natural gas industry, state regulation has concerned itself primarily with rate making to protect consumers from monopolistic price practices. ${ }^{40}$ For consumers of natural gas, like users of mantufactured gas and electricity, are tied to a single supplier. To prevent the wasteful building of overlapping lines, ${ }^{50}$ muncipalities and later state commissions ${ }^{51}$ have made regulated monopolies of single distributing companies. ${ }^{62}$

43. See King, Pooling and Unitization of Oil and Gas Leases, 46 MICr. L. Rev. 311 (1948) ; Myers, Spacing, Pooling and Field Wide Unitization, 18 Miss. L.J. 267 (1947).

In 1938 it was estimated that the cost of drilling of unnecessary wells ran between $\$ 80$ million and $\$ 100$ million per year. Ely, The Conservation of Oil, 51 HARv. L. REv. 1232-3 (1938).

44. These statutes authorize the regulatory agency to prescribe surface tracts of uniform size and shape on which only a single well may be drilled. E.g., OKLA. STAт. ANN., tit. 52, $\$ 87.1$ (Cum. Supp. 1949).

45. See Jacobs, Unit Operation of Oil and Gas Fields, 57 YALE L.J. 1207, 1209 (1948).

46. See id. at 1210 .

47. E.g., Mich. Stat. Ann. $\$ 13.138(20)$ (Rice Cum. Supp. 1949); N. M. StAT. $\$ 69-$ 213 (1942). These statutes permit the state commissions to form compulsory drilling units if gas is being wasted. Louisiana provides for the compulsory formation of drilling units without a finding of waste. LA. GEN. Stat. $\$ \S 4741.18-4741.19$ (Dart Supp. 1949).

48. OkLA. Stat. Ann., tit. 52, $\$ 286.4$ (Cum. Supp. 1949).

49. See Troxel, Economics of Public Utilities 213 (1947).

50. See $i d$. at 28 ; Bonbright, Public Utilities and the National Power PoliCIES 7 (1940).

51. By 1948 all but seven states had commission regulation of gas and elcctric utilities. FPC, State Commission Jurisdiction and Regulation of Electric and Gas Utidities 2, 16 (1948). For a history of the decline of local regulation and the shift to control by state commissions since the early part of the century, sce Troxen, $o p$. cil. stpra note 49, cc. 3,4 .

52. A utility is seldom granted the exclusive right to serve a particular area, but the common practice is to allow only one company to do so. See $i d$. at 194 . Before 1900 local 
While protecting consumers, courts and rate boards have also sought to permit utility earnings sufficient to cover operating costs plus a fair return on the company's property. ${ }^{53}$ The actual dollar amount-or rate base-on which the return was to be made was originally the "fair value of the [utility] property." How to determine this "fair value" has preoccupied rate makers and courts for two generations. 55

governments often relied on competition to control utility earnings, prices and service standards. In 1895, for example, Duluth, Mínnesota, had five competing clectric companies. Id. at 38. See also Barnes, The Economics of Puildic Utility Regulation 168-9 (1942). Some communities, like Pittsburgh, for example, are still served by more than one gas utility. Moody's, Pirble Utilities 76 (1949). But these companies operate under regulation rather than competition. See FPC, op. cit. supra note 51, at 16.

53. See BARNES, op. cit. supra note 52, at 314-15.

54. Courts were long hesitant to scrutinize rates set by legislatures. In Afunn v. Illinois, 94 U.S. 113 (1876), the Supreme Court refused to review the state fixing of grain warehouse rates, pointing out that rate making was a legislative, not a judicial, function. Several years later, in Stone v. Farmers Loan and Trust Co., 116 U.S. 307 (1886), the Court suggested in a dictum that it would review rates if the legislature had fixed them in bad faith.

A theory and formula for judicial review emerged in full bloom in Smyth v. Ames, 169 U.S. 466 (1898), where the Court, in passing on railroad rates set by Nebraslas, flatly asserted for the first time its right to review state-fixed rates. The Court stated its formula thus: "[T]he basis of all calculations of rates ... must be the fair value of the property being used for the convenience of the public. ... What the company is entitled to asls is a fair return on [that] value. ..." Id. at 546-7.

For a discussion of this early history see Barron, Ezolution of Smyth r. Ames, $28 \mathrm{VA}$. L. REv. 761 (1942). See also BARNES, op. cit. stipra note 50, at 314-15.

55. In Smyth v. Antes the Supreme Court said that in determining "fair value" such factors should be considered as "the original cost of construction, the amount expended in permanent improvements, the amount and market value of [the company's] bonds and stocks, the present as compared with the original cost of construction, the probable carning capacity of property under particular rates set by statute, and the sum required to meet operating expenses. . .." 169 U.S. 466, 546-7 (1898). One commentator has pointed out that operating expenses have no relation to a measure of value of the utility property. BARNES, op. cit. sttpra note 52, at 378.

This Supreme Court statement as it stood never became a rate making formula. But from the Court's insistence on the "fair value" test there evolved two different concepts of "cost" which, if not synonymous with "fair value," are often regarded as more or less significant "evidence" of it. The first concept is what the utility property actually cost. This embraces'the cost of the property to the person who first devoled it to public use ("original cost"), its cost of acquisition by the company whose rates were under consideration and, where the company's books were sloppily kept, a best guess as to what the property did cost (sometimes called "historical cost"). The second concent is what it would cost to replace the utility property ("reproduction cost"). At various times one and then the other of these concepts have dominated the courts' and commissions' attempt to find "fair value."

A third concept has been gaining headway since the mid-twentics, not as one of the "evidences" of "fair value" but as a substitute for the "fair value" rate base. This yardstick is what the utility property should have cost if its owners had spent visely" ("prudent investment"). 
An auxiliary problem, to which rate makers have paid far less attention, is what property to include in the rate base. Where the utility purchases raw materials at arm's length on the open market, the property of independent suppliers is obviously not part of the utility's rate base. All utilities are allowed to include the price paid as an operating expense. ${ }^{\text {Jo }}$ And where an electric or manufactured gas company owns a source of raw materials, stuch as a coal mine, this property is usually not included in the rate base. The utility merely recovers the going price for the raw materials as an operating expense. ${ }^{.77}$ Natural gas companies, on the other hand, receive different treatment. Where the production, transmission and distribution of gas are carried on by a single company or by affiliates within one state, rate makers in effect lump the whole system into a rate base for determining local rates. ${ }^{.8}$

For an excellent history of this development see BARNES, op. cit. supra note 50, at 370 403. See also Mr. Justice Brandeis, concurring, in Southwestern Bell Tel. Co. v. Comm'n, 262 U.S. 276, 289-94, 294 n.6 (1923) ; Hale, The Fair Value Merry-Go-Round, 33 ILt. L. REv. 517 (1939).

The "fair value" rate base was required by the Supreme Court in 1898 to satisfy the due process clause of the Fourteenth Amendment. Smyth v. Ames, 169 U.S. 466 (1898). The Court in 1943 discredited the "fair value" concept and held that compliance with the Fifth Amendment does not require any specific rate making formula. FPC v. Hope Nat. Gas Co., 320 U.S. 591 (1943). Nevertheless many states have continued to use "fair value." FPC, op. cit. supra note 51 , at 8 .

56. E.g., East Ohio Gas Co. v. City of Cleveland, 27 P.U.R. (N.S.) 387, 394, 414-17, 424 (Ohio 1939) (natural gas purchases from independents); Re Customers of Edison Elec. Illum. Co., 5 P.U.R. (N.S.) 369, 372-4 (Mass. 1934) (electric company's purchase of coal); Re Pub. Serv. Gas Co., P.U.R. 1922C, 493, 502-4 (N.J. 1922) (manufactured gas company's purchase of oil).

If a utility pays more than the "going" price for its fuel, the excess is disallowed. E.g., Re Citizens Mutual Heating Co., P.U.R. 1924A, 783, 785-6 (Ind. 1923) (coal purchases).

The most obvious current recognition of fuel expenditures as operating expenses is the "fuel adjustment" clause being written into local utility rate schedules. Thesc clauses tie the retail rates to changing fuel prices. E.g., $R e$ Haverhill Gas Lt. Co., 79 P.U.R. (N.S.) 423, $426-7$ (Mass. 1948) (manufactured gas company); Re Conn. Lt. \& Power Co., 44 P.U.R. (N.S.) 65, 68 (Conn. 1942) (electric and manufactured gas company). Sec also McQuillen, Current Developments in Electric Rate Making, 42 PUв. UTrL. Fort. 620 (1948); $R e$ Uniform Fuel Clause for Elec. Companies, 54 P.U.R. (N.S.) 57 (Conn. 1944).

57. E.g., Re Ramier \& Elgin, P.U.R. 1921C, 121, 131 (Tenn. 1921).

58. Where a single company is producer, transporter and distributor, all its property is usually included in one rate base for the purpose of setting local rates. E.g., Re United Fuel Gas Co., P.U.R. (N.S.) 1920C, 583, 585, 587 (W.Va. 1919).

More often these functions are split among affiliated corporate entities: One company may produce, transport, and sell gas wholesale to different distributing companies which in turn sell to local consumers. Faced with this setup the states usually first put the producertransporter's property into a rate base and fix his wholesale rates. E.g., State v. Lone Star Gas Co., 86 S.W.2d 484, 11 P.U.R. (N.S.) 283, 315 (Tex. Civ. App. 1935), rev'd on other grounds, 304 U.S. 224 (1938). The next step is to fix rates for each distributing company, allowing as an operating expense the wholesale purchase price paid to the affiliated pipeline, and allowing also a return on the distributing company's own rate base. E.g., Re Community Nat. Gas Co., 15 P.U.R. (N.S.) 149, 163, 164, 167 ('Tex. 1936) (affiliate of Lone Star 
State rate control could be effective as long as natural gas distributors and their sources of supply were located within the same state. But the consuming states ran into trouble as their local utilities began to draw increasing volumes of gas from pipelines that stretched out to producing fields in other states. Where these interstate pipelines were affiliated with local distributing companies the consuming states could compel the local company to prove the reasonableness of its pipeline purchase price at the peril of having it disallowed as an operating expense. ${ }^{59}$ As a practical matter, however, the states had difficulty getting the records of companies located outside their borders in order to check on costs. ${ }^{60}$ And where the local distributing company bought its gas from a non-affiliated interstate pipeline, state regulation of the wholesale price was forbidden as a burden on interstate commerce. ${ }^{01} A$ fortiorari the consuming state could not reach beyond the pipeline and regulate the price

Gas Co., supra). In effect, therefore, the local distributor's rates are fixed by a rate base method that reaches back to the producing property.

The alternative to including natural gas producing property in the rate base is to allow the gas company the "going" price for gas as operating expense, as is done with electric and manufactured gas companies which own their sources of fuel supply. Cf. Pennsylvaniz Power \& It Co. v. Pub. Serv. Comm'n, 193 Atl. 427, 19 P.U.R. (N.S.) 433, 441-3 (Pa. Super. Ct. 1937).

- Neither commissions nor courts have discussed the reasons for compensating utilities for natural gas production through the rate base rather than allowing them a price for the gas as an operating expense. Two reasons suggest themselves. In the first place the natural gas utility is the chief, often the only, market for gas in the field, while electric and manufactured gas utilities form a much smaller share of the total market for coal and oil. This means that the gas companies have a much greater hand in determining the "going" price for natural gas than the other utilities have in determining the market price for coal and oil. To allow gas companies the field price as an operating expense might let them lift themselves by their own bootstraps. See infra note 233. In the second place natural gas field prices are not as easily ascertained as the prices of cosl and oil. The determinstion of natural gas "market values" is made none the less in cases involving royalty disputes. E.g., Shamrock Oil \& Gas Corp. v. Coffee, 140 F.2d 409 (5th Cir. 1944), cert. denied, 323 U.S. 737 (1944).

For whatever reasons rate making bodies first included the producing property of natural gas utilities in the rate base, it is not hard to see why they have continued to follow this pattern. A natural gas utility tends to present itself to a commission, much more often than does a manufactured gas or electric company, as a system completely integrated from its source of supply to the customer's door. A continuous flow of natural gas from the field is much more important to a natural gas company than is the flow of cosl or oil to another utility. Thus from the earliest days, at the end of the last century, natural gas companies have been widely engaged both in production and distribution.

Mioreover the commissions, in applying the rate base method to production by natural gas utilities, heard little or no complaint from the companies until the FPC turned from a "fair value" rate base to one reflecting only actual cost. See pp. 1478-9 infro. NIr. Justice Jackson then took up the cudgel against this application of the rate base method. FPC v. Hope Nat. Gas Co., 320 U.S. 591, 652-3 (1943) (dissenting).

59. Western Distributing Co. v. Pub. Serv. Comm'n, 285 U.S. 119 (1932).

60. See Sen. Doc., supra note 29, at 608-9, 614; Troxel, op. cit. supra note 49 , at 95 .

61. Missouri v. Kansas Nat. Gas. Co., 265 U.S. 298 (1924). 
it paid to producers. These purchase prices were simply carried into the consumers' bills. ${ }^{62}$

Moreover, competition did not provide the regulation which the states could not. Potential rivals were reluctant to invade the holding company empires which pipelines bound together. ${ }^{63}$

\section{Growth of Federal Regulation \\ Control of interstate pipelines}

To plug the gap in state regulation, Congress in 1938 passed the Natural Gas Act. ${ }^{.4}$ The Act itself was based on a 7 -year investigation of interstate gas and electric companies by the Federal Trade Commission. ${ }^{65}$ It gave the Federal Power Commission the job of regulating the "transportation" and the "sale in interstate commerce of natural gas for resale for ultimate public consumption." The FPC was excluded from jurisdiction over "local distribution" and the "production or gathering of natural gas."

Pursuant to this authority the FPC began to control the interstate pipelines' wholesale rates to distributing companies. In regulating pipelines that owned producing property the FPC followed in part the pattern the states had set for intrastate pipelines. It lumped the pipeline's producing property together with its transmission property into a single rate base and allowed the pipeline to charge rates that would yield a fair return on their total property. ${ }^{67}$ But where the states had fretted over the "fair value" of utility property, the FPC quickly concerned itself only with the "actual legitimate cost" of the property to the company. ${ }^{68}$ From the "actual legitimate cost" the Commission deducted

62. See note 58 supra.

63. See SEN. Doc., supra note 29 , at $228-36,255-78$, 593. By the 'thirties four holding company groups-Electric Bond \& Share, United Corporation, Cities Service, and Standard Oil (N.J.) - controlled roughly a fifth of the country's gas production, id. at $589-90$, and four-fifths of its transmission lines. Id. at 591 .

64. 52 SтAт. 821 (1938), as amended, 15 U.S.C. $\$ 717$ (1946).

65. 52 STAT. 821, §1(a) (1938), 15 U.S.C. \$717(a) (1946); SEN. Doc., supra tote 29 , at $616-17$.

66. 52 STAT. 821, $\$ 1$ (b), as amended, 15 U.S.C. $\$ 717$ (b) (1946).

67. E.g., In Matter of Natural Gas Pipeline Co., 2 F.P.C. 218 (1940), affirmed, 315 U.S. 575 (1942). For the purpose of an interim rate order the FPC in this case accepted the pipeline's own estimate of reproduction cost as the starting point in arriving at a rate base. Id. at $227-9$.

68. City of Cleveland v. Hope Natural Gas Co., 3 F.P.C. 150, 44 P.U.R. (N.S.) 1 (1942). Hope claimed a rate base of $\$ 66$ million and sought to justify it by estimates of "reproduction cost" of $\$ 97$ million and "trended original cost" of $\$ 105$ million. Id. at 15G-\$. The Commission, however, included in the rate base only an "actual legitimate cost" of $\$ 51$ million, less $\$ 21$ million depreciation, which closely approximated Hope's own book cost. Id. at 159.

The Supreme Court upheld this procedure and administered the coup de grace to Smyth v. Ames, notes 54, 55 supra. FPC v. Hope Nat. Gas Co., 320 U.S. 591 (1943). Moreover, the Court hinted that the FPC had considerably more leeway in setting rates than it had taken advantage of in this case. See note 221 infra. 
accrued depreciation and depletion to arrive at a "net investment" or "prudent investment" rate base. ${ }^{69}$

The pipelines attacked both this use of actual legitimate cost and the inclusion of their producing property in the rate base. But the Supreme Court backed up the FPC. ${ }^{70}$ In effect, therefore, the FPC did gain a measure of price control over production that was integrated with interstate pipelines.

\section{Dispute over regulation of independent produccrs}

But what was the FPC supposed to do about the price of gas purchased at arm's length from independent producers?

In 1940 the Columbian case ${ }^{71}$ presented this question for the first time. In this case the FPC decided that it could not regulate independents' prices. But the decision set the tone for the 10-year controversy that has followed.

Sale by an independent, at the conclusion of production and gathering, seems to be a "sale in interstate Commerce. . . . for resale" within the wording of the Natural Gas Act. But is it a "sale . . . for resale" within the meaning of the Act? It is difficult to credit Congress with having conferred this authority on the FPC at a time when the advisability of regulating the independents' sales had never been considered. The Federal Trade Commission, in its lengthy study of interstate natural gas companies, scarcely mentioned the independent producers, and then only to lament their plight at the hands of the pipelines.72 To help the independents it recommended no federal measures, but the adoption of state conservation practices. ${ }^{73}$ Congress, in debates and hearings on the bills that developed into the Natural Gas Act, gave no attention to the regulation of independents' sales. Its only concern was with the interstate pipelines. ${ }^{74}$

69. While the FPC did not use the term "net investment" or "prudent investment" in the Hope case, see note 68 stpra, former Commissioner Olds regarded the case as establishing that principle for rate making. Hearings, stpra note 2, at 230-1. After the Hope case the FPC spelled out the principle in greater detail. In Maller of Miss. R. Fuel Corp., 4 F.P.C. 340 , 344 (1945). See FPC, ANs. REP. 1946, 7-S (1947); Bonbright, Contribustions of the FPC to the Establishment of the Prudent Iniestment Principle of Rate Mal:ing, 14 Geo. WASH. L. REv. 136 (1945); Hale, Utility Regulation is the Light of the Hope Natural Gas Case, 44 CoL. L. Rev. 488, 495 (1944).

The FPC had previously used the prudent investment principle, however, in its regulation of electric utilities. See In M1atter of Chi. Dist. Elec. Generating Corp., 2 F.P.C. 412, 416-20 (1941).

70. FPC v. Hope Nat. Gas Co., 320 U.S. 590 (1943) (actual legitimate cost); Colorado Interstate Gas Co. v. FPC, 324 U.S. 581 (1945) (producing property in rate base).

71. In re Columbian Fuel Corp., 2 F.P.C. 200 (1940).

72. SEN. Doc., supra note 29, at 132-3, 184-97, 590-1.

73. Id. at 616, recommending in addition a federal "hot gas" statute to back up state conservation. Passage by Congress of a "hot gas" act has also been suggested in reent years. See SyITH-WingERLY REP. 143-4.

74. See 81 Cong. Rec. 6721, 9312 (1937) (debate on H.R. 6585, 75th Cong., 1st Sess., the bill that became the Natural Gas Act); Hearings before House Commitfec on Inferstate Comnerce on H.R. 11662, 74th Cong., 2d Sess. 28, 32, 34, 42-3 (1936) (on predeces- 
The legislative history of the Act persuaded a majority of the Commission in the Columbian case that Congress had intended to regulate only the interstate pipelines and their sales for resale to local distributing companies. ${ }^{75}$ But then the majority hedged, saying that a change of mind might be called for if the future showed that the independents were "able to maintain an unreasonable price despite the appearance of competition." 76 One dissenting Commissioner, however, was ready to regulate these independents' sales then and there. ${ }^{77}$

Since the Columbian decision the independents have been haunted by the fear that the Commission might change its mind. ${ }^{78}$ And subsequent events

sor bill). A spokesman for coal producers saw this elimination of gas production control as a defect in the bill. Id. at 71-2. See also Hearings, supra note 2, at 485-91 (bricf of Nat'l Ass'n of Railroad and Util. Comm'rs).

Companion bills that would have specifically granted the FPC jurisdiction over the "procurement" of natural gas for interstate pipelines were not adopted. H.R. 5711, S. 911, 75th Cong., 1st Sess. (1937).

75. 2 F.P.C. $200,205-7$ (1940).

76. Id. at 208.

77. Former Commissioner Scott, id. at 209. He relied on the wording of the Act ("sale in interstate commerce ... for resale"), id. at 210 , and on the statement in a Congressional report that the purpose of the Natural Gas Act was to close the gap that existed in state regulation. Id. at 209. The "sale" of gas in interstate commerce was beyond the jurisdiction of the states, he argued, and therefore the Act conferred FPC jurisdiction over such sales. Id. at 216-17.

The House and Senate reports on the bill that became the Natural Gas Act contained this statement: "[I]n the case of sales for resale or so-called wholesale sales, in interstate commerce (for example, sales by producing companies to distributing companies) the legal situation [is such that the states cannot regulate them]. Such transactions have been considered to be not local in character and, even in the absence of congressional action, not subject to State regulation (See Missouri v. Kansas Gas Co., 265 U.S. 298 (1924); and Public Utilities Commission v. Attleboro Steam \& Electric Co., 273 U.S. 83 (1927)). The basic purpose of the present legislation is to occupy the field in which the Supreme Court has held that the States may not act." H.R. REP. No. 709, 75th Cong., 1st Sess. 1, 2 (1937) ; S. REp. No. 1162, 75th Cong., 1st Sess. 2 (1937).

On this statement has rested the argument by proponents of FPC regulation of independents' prices that Congress intended in the Natural Gas Act to confer such jurisdiction. See, for example, H. Rep. No. 1140, 81st Cong., 1st Sess. 10 (minority report opposing amendment of the Act to exempt independents); Hearings, supra note 2, at 213 (Former Federal Power Commissioner Olds); id. at 499 (Commissioner Buchanan).

The crucial question is what "gap" in state regulation Congress intended to close. The only indication that this gap included independents' sales to interstate pipelines is the reference to "producing companies" in the Congressional reports, stipra, followed by the citation of Missouri v. Kansas Gas Co., 265 U.S. 298 (1924), and Pub. Serv. Comm'n v. Attleboro Steam \& Elec. Co., 273 U.S. 83 (1927). But in these cases the Supreme Court barred state regulation of companies that were not only producers but also interstate transporters. This situation parallels that of the interstate pipelines, who clearly werc intended to be federally regulated by the Natural Gas Act, rather than that of the independent producers of natural gas. For further indication of this intent see note 74 supra.

78. See SMith-W Mnrerey Rep. 155, 166-8; Hearings, siepra note 3, at 42, 77, 277-8; Hearings, supra note 2 , at 504 . 
have done little to allay this fear. In actual practice the FPC has allowed the interstate pipelines to recover, as operating costs, the arm's length prices paid to independent producers. ${ }^{73}$ But the Commission's stand has been confusing. For a time the FPC seemed to maintain simultaneously that it had jurisdiction over independents' sales and also that it did not. While its General Counsel was publicly affirming the narrower view, ${ }^{80}$ the FPC was asserting the broader view in the Interstate case. ${ }^{81}$

In this case the Commission ordered a reduction in the price at which one interstate pipeline sold gas to another interstate pipeline within the producing state. The FPC might have asserted jurisdiction over this sale on the ground that the seller was an interstate pipeline. Instead it chose to justify its regulation by adopting the view that all sales in interstate commerce for resale were under its wing. ${ }^{82}$ Before the Supreme Court the Commission drew back to rely on the fact that the sale it sought to regulate was made by an interstate pipeline. ${ }^{83}$ But the Supreme Court in 1947 upheld this regulation in language that seemed to say that all sales in interstate commerce for resale were within the reach of the Commission. ${ }^{84}$

Alarmed at these confusing developments, the independents early in 1947 sought congressional amendment of the Natural Gas Act to explicitly exclude FPC regulation of their sales to interstate pipelines. ${ }^{80}$ Endorsing this pro-

79. E.g., City of Cleveland v. Hope Nat. Gas Co., 3 F.P.C. 150, 183 (1942), ofirmed, FPC v. Hope Nat. Gas Co., 320 U.S. 591 (1943).

80. Shannon, Effect of Recent Suprente Court Decisions on the Prodisclion and Gothering of Natural Gas, INTErstate Oil Compact Q. Bule. 41 (June 1945).

81. In re Interstate Nat. Gas Co., 3 F.P.C. 416 (1943).

82. Id. at 421. The FPC continued to urge this broad interpretation of its jurisdiction before the Fifth Circuit. Brief for Appellee, p. 12, Interstate Nat. Gas Co. v. FPC, 156 F.2d 949 (5th Cir. 1946), quoted in Sarrta-IVrsmerty Report 169. On the way up to the Supreme Court the FPC still stuck by its guns. Brief for Respondent in opposition to petition for certiorari, p. 12, Interstate Nat. Gas Co. v. FPC, 331 U.S. 6S2 (1947).

83. Brief for Respondent, pp. 34-5, Interstate Nat. Gas Co. v. FPC, 331 U.S. 682 (1947).

84. "... By the time the sales are consummated, nothing further in the gathering process remains to be done. We have held that these sales are in interstate commerce. It cannot be doubted that their regulation is predominately a matter of national, as contrasted to local concern. All the gas sold in these transactions is destined for consumption in States other than Louisiana. Unreasonable charges exicted at this stage of the interstate movement become perpetuated in large part in fixed items of costs which must be covered by rates charged subsequent purchasers of the gas, including the ultimate consumer. It was to avoid such situations that the Natural Gas Act was passed." Interstate Nat. Gas Co. v. FPC, 331 U.S. 682, 692-3, relscaring denicd, 332 U.S. 785 (1947).

85. Four identical bills were introduced in the first session of the 80th Congress: S. 724, H.R. 2185, 2235, and 2292 (1947). The three House bills were later replaced by the Rizley bill, note 87 infra.

Also seeking relief in these bills were the pipeline-producers, angered at the FPC's inclusion of producing property in their rate bases at actual cost (less depreciation and depletion). See note 68 supra. The pipelines' section of the bills would have prohibited 
posal, the FPC reaffirmed its original view that it did not have jurisdiction over such sales. ${ }^{86}$ But from 1947 to 1949 the independents' proposal was stalled in Congress. ${ }^{87}$

Meanwhile the position of the FPC began to shift, as its membership changed, in favor of regulating the independents' prices. ${ }^{88}$ By 1949 a majority of the

the FPC from compensating pipelines for their own production by including producing property in the rate base at any valuation. Instead the FPC would have been forced to allow them as an operating expense the "market price" or the "fair and reasonable valte" of the gas they produced.

A "market price" allowance would have opened the door to price rigging. Sec note 233 infra. A "value" allowance would have brought a return to the old "fair value" rate base. Unless the figure representing the "value" of the gas were pulled out of a hat, the FPC would first have had to find the "value" of the producing property, calculate operating expenses, and set an allowance that would cover expenses plus a return on the "value."

The entire FPC opposed these bills on the ground that action should await completion of its fuel investigation, note 8 supra. FPC report on S. 734, H.R. 2185, 2292, and 2569, Hearings before House Committee on Interstate Commerce on H.R. 21\$5, 2235, 2292, 2569, and 2956, 80th Cong., 1st Sess. 10 (1947). Later Commissioners Smith and Wimberly proposed an amendment, Hearings before Senate Committec on Interstatc Commerce on H.R. 4051, 80th Cong., 2d Sess. 90 (1948), that Commissioner Draper regarded simply as another variation of the Rizley bill. Id. at 544 .

86. Ietters to House Committee on Interstate Commerce from FPC, dated June 27 and July 10, 1947 (11 days and three weeks, respectively, after the Interstate decision was handed down), quoted in H. REP. No. 1140, 80th Cong., 1st Sess. 3-4 (1949).

This approval was soon followed by the Commission's famous Order 139, announcing that, pending Congressional action, the FPC would not move to regulate sales by independents to interstate pipelines. FPC Docket No. R-106, Order No. 139 (Aug. 7, 1947), printed in Hearings, supra note 2 , at 520 . Under this order the FPC has exempted a number of independents. E.g., Delhi Oil Co., OrL \& Gas J. 201 (Mar. 17, 1949) ; Fin-Ker Oil \& Gas Production Co., 6 F. P. C. 92, 69 P.U.R. (N.S.) 85 (1947).

87. The Rizley bill, carrying both relief for the pipelines and exemption for the independents, did pass the house. H.R. 4051, 80th Cong., 1st Sess. (1947), 93 Cong. Rec. 8751 (1947). But it was killed in Senate Committee. 94 Cong. REc. DAILy Digest D345 (1948).

The next move was to shear off the pipeline measure and aim solely at exemption for the producers. This had first been tried in H.R. 4099, introduced as a substitute for the Rizley bill but never acted on. After the failure of the Rizley bill the producers' measure was revived in S. 2757, 80th Cong., 2d Sess. (1948). But the Congress ended without acting on the bill.

At the start of the 81st Congress another try was made. S. 1498, H.R. 79, H.R. 1758, 81st Cong., 1st Sess. (1949). Later a proposal to exempt producers selling less than two billion cubic feet of gas annually to interstate pipelines was indorsed by the FPC. Stupplemental Hearings before Subcommittee of House Committee on Intcrstate Commerce on H.R. 79, 1758, 982, 81st Cong., 1st Sess. (1949). Nothing was done with this proposal.

The Harris bill, H.R. 1758, passed the House late in 1949. 95 CoNG. Rzc. 10871 (1949).

88. The shift began as follows :

1947 : Commissioner Sachse resigned, leaving a four-man Commission. Members Smith, Olds and Wimberly then sided with the independents, with Draper in opposition. 
Commission ${ }^{89}$ hinted that unless Congress forbade them to regulate they might do so. ${ }^{90}$ Congress responded by turning down the renomination of Commissioner Olds, chief spokesman for regulation. ${ }^{31}$ The proposal to exclude the independents from FPC jurisdiction finally emerged as the Kerr bill. ${ }^{02}$ After it had squeaked through Congress, early in $1950,{ }^{03}$ the President vetoed it. ${ }^{01}$

Whether the FPC will now assert jurisdiction over independents' sales to interstate pipelines is uncertain. ${ }^{35}$ The answer may come in a proceeding now pending before the Commission to determine whether the Phillips Petroleum Company, largest seller of gas to interstate pipelines," is a "natural gas company" under the Natural Gas Act.97 The outcome depends a lot on the yet un-

FPC Docket No. R-106, Order No. 139 (Aug. 7, 1949), printed in Hearings, sufra note 2, at 520 .

1948: Olds joined Draper in opposing the independents, Draper-Ords REr. 12, and in hinting at FPC regulation. Id. at 158. Yet at the same time Olds seemed to declare that he had no desire to regulate the independents Hearings, supra note 2, at 267 (Olds reading from his statement made in 1948). See also id. at 93.

89. New Commissioner Buchanan joined the evenly split Commission of 1948, note 88 supra, and sided with Draper and Olds against the independents. Hearings supro note 3 , at 167-74 (FPC report on bills). See also note 90 infra.

90. This majority agreed that they did have jurisdiction over the independents' sales to interstate pipelines. Hearings, supra note 2, at 248 (Olds), 387 (Draper), 419 (Buchanan). They announced, moreover, that unless Congress acted they would rescind their Order No. 139, supra note 86, exempting such sales. Supplemental Hcarings, supro note 7, at 321 (Olds), 352 (Buchanan and Draper). This was done shortly after the President's veto of the Kerr bill. See note 95 infra.

91. 95 CoNG. Rec. 14386-7 (1949).

92. S. 1498, 81st Cong., 1st Sess. (1950).

93. The Senate substituted the language of the Kerr bill for the House-approved H.R. 1758 and passed the House bill as amended. 96 Corg. REc. 4365 (Mar. 29, 1950). The House concurred. Id. at 4631-2 (Mar. 31, 1950). Thus the Kerr bill was the one adopted by Congress, if not technically, at least in substance.

94. H. R. Doc. No. 555, 81st Cong., 2d Sess. (1950).

95. In July, 1950, the five-man FPC unanimously rescinded the famous three-yearold Order No. 139, exempting independents from regulation, note 86 supra. The new Chairman Wallgren joined Commissioners Buchanan and Draper in stating that their action stemmed from the President's veto of the Kerr bill; that the FPC did not intend to start a general investigation of producers' prices; and that after "further studies of the operation of producers .... the commission plans to promulgate rules and regulations specifically applicable to them." Commissioners Smith and Wimberly stated that they acquiesced in the rescission of Order No. 139 only because it "does not accurately reflect the interpretation placed by the majority on the Natural Gas Act and therefore the policy of the commission." They said they would elaborate their views in a concurring opinion to be filed later. FPC Turnabout, OIL \& GAS J. 50 (Jul. 20, 1950).

96. Hearings, supra note 2 , at 18.

97. See Phillips Hearing, OIL \& Gas J. 78 (Feb. 16, 1950) ; Phillips Hearing Postponted, OIL \& GAS J. 285 (Oct. 5, 1950) (postponed to Jan. 8, 1951).

An FPC attempt to regulate Phillips' sales need not squarely test the Commission's jurisdiction over independents, since Phillips' status as an "independent" producer, see pp. 1490-92 infra, is precarious. Phillips transports gas from its Oblahoma wells into Tesas 
known view of new Commissioner Wallgren, who holds the balance of power in an evenly split Commission.

Lurking in the background of the Phillips and subsequent proceedings, and perhaps vitally affecting their outcome, are the growing importance of the independents' sales to interstate pipelines and the shadow of rising prices in the face of an unprecedented demand for natural gas.

\section{The "Field Price" Problem}

\section{Significance of field prices}

Since the start of World War II many parts of the country have been hit by increasingly acute shortages of natural gas. The pipelines simply have not been able to pump through enough gas to supply everybody who wants it.08

In the face of this insatiable demand spokesmen for the consumer states, during the Kerr bill controversy, began to show a new interest in the role of the independent producer in the natural gas industry. ${ }^{00}$ The price received by the independents in their sales to interstate pipelines-loosely called the "field price"100 - is the only price along the line from well to consumer that has gone

before selling it to interstate pipelines. See Letter to Sen. Gillette from Federal Power Commissioner Wallgren, dated Mar. 22, 1950, 96 Cong. Rec. 4060 (Mar. 22, 1950). This might make Phillips an interstate pipeline.

Phillips recently sold its stock in its subsidiary Independent Natural Gas Co., an interstate pipeline. Ralph, Test of Power, OrL \& GAS J. 133 (Apr. 20, 1950).

98. See FPC, ANN. REp. 1949, 112-13 (1950); Id. 1948, 84-90 (1949); Id. 1947, 72-7, 99-100 (1948).

99. See letters and telegrams, for example, in 96 Cong. REc. 3315 (Mar. 14, 1950); id. at 3846-8 (Mar. 22, 1950); id. at 4247 (Mar. 28, 1950).

100. Natural gas is sold in the field under long-term contracts. See p. 1498 infra.

The term "field price" is used variously to denote for a given area:

(1) The "going" price that a buyer must offer to get a contract for additional gas. This price is a matter of rumor in the fields.

(2) The average weighted contract prices at which gas is being delivered to:

(a) interstate pipelines. This is the meaning of "field price" as used in this Comment, and sometimes as used by the Federal Power Commission. The FPC has published these prices, however, only for the southwestern area for 1944 and 1947. SMITH-WIMBEnLY REP. 182; Hearings, supra note 2, at 18, Table 12. In the last two years it has also reported the prices paid by a number of interstate pipelines and those received by a number of independent producers in that region. Id. at 18-19 (prices in 1947); Smitu-W ImberLY REP. 182 (various prices 1939-1946).

(b) all buyers in the field, including intra-state pipelines, local industrial uscrs, and other producers. The nearest thing to a record of these prices are the Bureau of Mincs' figures showing the average of what it calls the "well-mouth" prices of natural gas, by states, for each year since 1922. See Smith-Wimberly Rep. 179, Chart 1. The FPC las arranged these "well-mouth" prices to obtain regional averages. Ibid.

It is not clear just what the Bureau means by "well-mouth" price. Id. at 180 n.17. It seems to range below the field price paid by interstate pipelines. In 1944, for cxample, wellmouth prices in the southwest averaged 2.9 cents per thousand cubic fect, $i d$. at 179 , compared with a field price of 4.36 cents. Id. at 182 . In 1947 the well-mouth price was 3.7 cents, Hearings, supra note 2 , at 25 , Chart 1 , the field price, 4.65 cents. Cf. id. at 18 , Table 
almost untouched by government control.101 Moreover, under the present pattern of retail and pipeline rate regulation followed by the states and the FPC, a rise in the field price is reflected directly in the consumer's gas bill. ${ }^{102}$

So far the field price has represented a comparatively small slice of end rates to domestic and commercial users. ${ }^{103}$ These consumers have cause for alarm, however, in the growing importance of the independent producers as sources of natural gas supplies, and in the recent trend toward rapidly rising field prices.

\section{Growing importance of independents' sales}

Before World War II the big interstate pipelines made sure of a large part of their supply by purchasing or leasing acreage and going into the producing business. ${ }^{104}$ They also bought varying amounts of gas from independent producers. ${ }^{105}$ Today these purchases form a growing share of the pipelines' requirements. In 1947 , throughout the southwestern area producing four-fifths of the nation's gas, ${ }^{106}$ interstate pipelines bought 62 per cent of their gas from independents; in 1952 they will buy an estimated 77 per cent. ${ }^{107}$ And the

12. [This 1947 field price is the average paid by 17 interstate pipelines who purchased 997 billion of the one trillion cubic feet of gas bought by all interstate pipelines in the area. Id. at 16 , Table 8.]

In spite of the difference between field prices and "well-mouth" prices, the FPC has used the Bureau's figures to indicate the trend of field prices. See Hearings, supra note 2, at 220-1.

Well-mouth prices vary widely between producing areas, depending chicfly on their proximity to markets and the extent of their reserves. Prices are highest in the old Appalachian fields of the northeast, SurITH-WIMrBERLY REP. 179, which now hold only 2.5 per cent of the nation's reserves. Hearings, supra note 2, at 202. Prices become generally lower as purchases are made closer to the southwestern area, see Surrm-WIsserLY REP. 179-80, which is more distant from the big markets and has 88 per cent of national reserves. Hcarings, supra note 2 , at 13, Table 1. Field prices follow this pattern. In 1944, for example, interstate pipelines paid an average of 21.7 cents per thousand cubic feet for gas in the small fields of Pennsylvania; 15.3 cents in Kentucky; and 4.3 cents throughout the states of Kansas, Louisiana, Mrississippi, New Mexico, Oklahoma, and Tesas. Surrru-Wnursercy REP. 182.

The price of natural gas in the field also may vary widely within the same ares, depending on when the long-term contracts setting prices were made. Id. at 181.

101. The only "control" of these prices so far has been a price floor under all gas sales in the Kansas and Oklahoma areas of the tri-state Hugoton field. See pp. 1501-2 infro.

102. The pipelines' purchase price of natural gas is an operating expense to be recouped from rates. See pp. 1476, 1481 sipra.

103. See note 192 infra.

104. See SEN. Doc., supra note 29 , at 72-5, 160-4. The pipelines aequired large blocks of acreage from the original discovers of the fields at relatively low cost. See SurrnWIMBERLY REP. 184.

105. See SEN. Doc., supra note 29, at 72-3, 164-9, 472-3, Table 74.

106. In 1945 the states of Texas, Louisiana, Oklahoma, Kansas and New Mrexico supplied approximately 873 billion cubic feet, or 79 per cent, of the 1.1 trillion cubic feet of natural gas transported in interstate commerce. Sarrth-W WusBerLy Rer. 250, Table 4.

107. Hearings, supra note 2 , at 16. 
giant pipelines projected into that region since the war are buying virtually their entire volume from independent producers. ${ }^{108}$

\section{Upward trend of field prices}

Until the end of World War II, well-mouth prices slid steadily down hill. ${ }^{109}$ They then began creeping upward. ${ }^{110}$ From 1939 through 1946 field prices paid by interstate pipelines in the southwest remained fairly stable. ${ }^{111}$ In 1947 the big pipelines paid average prices ranging from 3.54 to 7.62 cents per thousand cubic feet, for an overall average of 4.65 cents. ${ }^{112}$ But in contracts negotiated in recent years the price has been steadily climbing. A review of 57 contracts made by interstate pipelines in Texas and Louisiana from 19468 showed an average starting price of 7.5 cents and in some cases 9 or 10 cents. ${ }^{113}$

The trend of most recent prices is perhaps illustrated by a look at the experience of the Phillips Petroleum Company, a big target of advocates of wider FPC authority in the recent Kerr bill controversy. ${ }^{114}$ Phillips is the chief "independent"115 supplier of interstate pipelines in the southwest, with the largest single holdings, amounting to about one-sixth of the acreage, in the country's two largest fields. ${ }^{116}$ In 1947 Phillips furnished 11 per cent of the pipelinepurchased gas in the southwest, ${ }^{117}$ or 5 per cent of the total requirements of all interstate pipelines. ${ }^{118}$ Its average price for these sales was 3.9 cents per thousand cubic feet. ${ }^{119}$ In 1948 Phillips contracted to supply at 5 cents a specified volume of gas that was enough to satisfy the then anticipated requirements of the new Michigan-Wisconsin pipeline. ${ }^{120}$ During the next two years, as the pipeline sought more gas, the initial contract was modified and the price boosted

108. Id. at 270,318 .

109. The Bureau of Mines' "well-mouth" averages, see note 100 stupra, in the southwest declined from 4.3 cents per thousand cubic feet in 1926 to 2.2 in 1940. SMITH-W REP. 179. In these days pipelines were often able to contract for gas at 1 or 2 cents. Sec SEN. Doc., supra note 29, at 207.

110. From 2.2 cents in 1940 the "well-mouth" price in the northwest rose to 3.7 in 1947. Hearings, supra note 2 , at 361 .

111. SMITH-WIMBERLY REp. 182.

112. Hearings, supra note 2 , at 18 , Table 12 .

113. Hearings, supra note 2 , at 223.

114. See, for example, Hearings, supra note 2, at 282, 328; 96 Cong. REc. 3514 (Mar. $16,1950)$.

115. This status is, however, currently in doubt. See note 97 stipra.

116. Hearings, supra note 2 , at 369 , Table 6 .

117. Phillips sold 116 billion cubic feet, $i d$. at 18 , Table 14 , out of a total of 1 trillion. Id. at 16 , Table 8.

118. Phillips' sales were 116 billion cubic feet, id. at 18 , Table 14 , out of 2.266 trillion. Id. at 16, Table 7.

119. Id. at 18, Table 14.

120. Letter to Sen. Douglas from FPC, dated Mar. 17, 1950, 96 Cong. REc. $3697-8$ (Mar. 20, 1950). 
to 7.6 cents and then to 8.5 cents. Later in 1949 Michigan- Wisconsin signed two new contracts for Phillips' gas, one starting at 10.2 cents and the other at 12.3 cents. ${ }^{121}$

Even current contract prices for natural gas are not firm. Most of the independents' contracts contain "escalator" clauses calling for automatic price rises of a cent or so every few years. Many of them also bind the pipeline to match any higher prices it pays to other sellers. And a few require the pipelines to meet any higher price paid by any other buyer in the area. ${ }^{120}$

\section{Mushrooming demand}

Factors Behind Rising Field Prices

The sensational recent jump in natural gas consumption stems in part from the advantages of natural gas as a fuel. Its cleanliness and push-button availability give natural gas a decided edge over coal and oil for household and commercial cooking, refrigeration and water heating. ${ }^{123}$ It has an advantage, somewhat less marked, in space heating. ${ }^{124}$ And it also affords the close temperature control desired in the production of such goods as high-grade alloys, glass and ceramics. ${ }^{125}$ To obtain these advantages, consumers have been willing to pay a premium price over coal and oil.120 And although natural gas shares most of its advantages with manufactured gas and electricity, it is far cheaper than either. ${ }^{12 \pi}$

121. See FPC data on pipeline purchase contracts, 96 CoNG. Rec. 3692-3 (ALar. 20, 1950). Michigan-Wisconsin maintains that these price increases will not be passed on to consumers. The increased volume of gas, it claims, will result in lower unit transmission costs that will actually lower projected wholesale rates. 96 CoNG. Rec. 3515 (Arar. 16, 1950); id. at 3835 (Mar. 22, 1950). See p. 1488 infra.

122. See summary of contracts printed in 96 Cong. Rzc. 3646 (Mfar. 17, 1950). The contract provisions requiring pipelines to match higher prices are called "most-favored nation" clauses. Supplemenfal Hearings, supra note 7, at 300 .

123. SMITH-WIMBERLY REP. 349, 400-2.

124. Natural gas has an advantage over oil for space heating in that gas requires no storage facilities on the user's premises. Over coal it has the further advantages of cleanliness and even heat. See $i d$. at 403-6.

125. Id. at 389-90.

126. See p. 1489 infra. Domestic customers use about a third of the natural gas sold by utilities but foot half the bills. Estimates for 1949: residential users accounted for 900 billion cubic feet of the utilities' 3 trillion cubic feet sold, and paid $\$ 582$ million of a total revenue of $\$ 1.1$ billion. Duff, Natural Gas Turns in Another Record Brcaling Pcrformance, OIL \& GAS J., 207, 208 (Jan. 26, 1950).

127. Residential rates for manufactured gas average more than double those for straight natural gas. See SxITh-IWrisberly REp. 339, Table 17. And since manufactured gas has roughly only half the heating value as the same volume of natural gas, see id., n.1, the equivalent heat unit price of manufactured gas is nearly four times as great as that of straight natural gas.

The absence of a national average for electric rates forces comparison with natural gas rates within particular communities. At the cheapest available rates, residential customers in Detroit and Dallas, for example, would pay seven times as much for a million B.t.u.'s of 
The bulk of natural gas consumption, however, has been simply as a lowcost industrial fuel competing on a price basis with coal and oil. ${ }^{128}$ If pipelines served only the premium-priced "convenience" users they would have to operate much of the time at well below peak capacity, since this demand fluctuates with the weather and seasons.120 To fill in the "valleys" of demand, and lower their unit transmission costs, pipelines have generally carried additional volumes of gas for "interruptible" sale to industries, at low rates, subject to curtailment in favor of domestic and commercial users. ${ }^{\mathbf{1 3 0}}$

In recent years, however, the demand for natural gas has received an enormous impetus from the sharp upward price trend of competing coal and oil.181

electricity as for natural gas. In Detroit the cheapest domestic gas rate for one million B.t.u.'s is 90 cents. Moody, Public Utilities 318 (1940) (rate of 9 cents per 100 cu. ft. for consumption over $2,000 \mathrm{cu}$. ft., converted according to standard, note $128 \mathrm{infra}$ ). The comparable electric rate would be $\$ 6.59$. Id. at 6 (rate of 2.25 cents per kwh for consumption over $250 \mathrm{kwh}$, converted according to formula in KENT, MECrinNICAL ENGINEERs' Handвоox 592, Table 2 (10th ed. 1923)). In Dallas the cheapest domestic gas rate is 61.2 cents for one million B.t.u.'s. MOody, supra, at 1327 (rate of 61.2 cents per thousand cu. $\mathrm{ft}$. for consumption over $7,000 \mathrm{cu}$. ft.). The comparable electric rate is $\$ 4.40$. Id. at 1526 (rate of 1.5 cents per kwh for consumption over $167 \mathrm{kwh}$, converted according to formula in KeNT, supra).

128. In 1945, for example, industry used 78 per cent of the country's total marketed production of natural gas, SMITr-WIMBERLY REP. 407, and paid an average of 15.8 cents per thousand cubic feet. Id. at 343 , Table 18. The average wholesale price for mine run bituminous coal in that year was $\$ 5.33$ per ton. SURVEY of CURRENT Business S-33 (U.S. Dept. Comm. Mar. 1946). The average refiners' price for No. 2 fuel oil was 3.63 cents per gallon in Oklahoma and the midwest, and 6.21 cents at New York harbor, SMIri-WuMBERLY REP. 346, Table 20. (Wholesale prices to large users. Id. at 345.)

These fuel prices may be translated into prices for equivalent heat units-price per million B.t.u.'s-by the following standard: natural gas, 1,000 B.t.u.'s per cubic foot; bituminous coal, 13,200 B.t.u.'s per pound; furnace oil, 135,000 B.t.u.'s per gallon. Id. at 339, Table 17 n.1. (Furnace oil includes Nos. 1 and 2 fuel oil. Id. at 347, Table 21). Comparative fuel prices calculated by this standard are at best, however, only rough approximations which ignore such significant variable factors as differences in utilization efficiency, seo id. at 348-50, regional price differentials, and periodic price fluctuations.

Under this simple conversion standard, the average fuel price per million B.t.t.'s to industrial users in 1945 was about 15.8 cents for natural gas, 20 cents for soft coal, 26 cents for fuel oil at Oklahoma and midwest refineries, and 46 cents for fuel oil at New York.

But along with fuel prices the consumer takes into account the dependability of his service. "Interruptible" service to industrial users of natural gas, see text infra, calls for rates lower than those obtainable in simple price competition with coal and oil. Sce Surru* WIMBERLY REP. 293.

129. See id. at $254-5$.

130. Id. at 256,275 . This reason for low-priced industrial sales may vanish with the development of storage facilities near markets. See $i d$. at 276-87. The most practical method is that of underground storage in depleted fields. Id. at 276-8. In 1946 an estimated 105 billion cubic feet of natural gas was stored in this way. Id. at 282. The capacity of projects under consideration is estimated at a minimum of 250 billion cubic feet. Id. at 285. For recent developments and a general discussion see Ball, Underground Gas Storage, Am. Gas Ass'n, Nat. Gas Dep't, Proceedings 35 (1949).

131. See Suyth-WramerLy REP. 330-1, 337-45. 
In 1940 natural gas cost domestic consumers an average of roughly 64 cents per million B.t.u.'s, compared with costs, for equivalent heat units, of 33 cents for soft coal and 51 cents for oil. By 1947 these figures were in the neighborhood of $59,55^{132}$ and 89 cents, ${ }^{133}$ respectively. Meanwhile the average pipeline industrial rate for natural gas remained stable at about 17 cents per million B.t.u.'s. ${ }^{134}$ But large buyers watched average comparable coal prices rise from 16 to 28 cents, ${ }^{135}$ oil prices at midwest refineries go from 25 to 52 cents, and at New York from 35 to 57 cents. ${ }^{130}$ This shift also caused manufactured gas companies, in whose rates the cost of coal or oil is a major factor, to turn to mixed or straight natural gas. ${ }^{137}$

The extent of the demand for natural gas is indicated by the increase in national consumption from 2.7 trillion cubic feet in 1940 to 4.4 trillion in 1947. ${ }^{138}$ In 1947 , interstate transmission totaled 1.3 trillion cubic feet. If the facilities presently authorized or applied for are built, the volume will reach roughly 3 trillion cubic feet. ${ }^{139}$

In the face of this boom it seems natural enough at first that the field price of gas should be going up. 140 Yet "proved" natural gas reserves have continued to grow steadily ahead of consumption. ${ }^{141}$ In 1931, for example, reserves stood at 20 times the then annual rate of withdrawal; in 1947 reserves represented a 30 years' supply at a much higher production rate. ${ }^{142}$

This picture of rising field prices in the face of faster-rising reserves presents an apparent anomaly. One explanation may lie in the fuzziness of information on reserves. "Proved" reserves are at best only rough estimates that

132. Id. at 339, Table 17 .

133. Id. at 339.

134. Hearings, supra note 2 , at 362 . For conversion standard see note 128 supra.

"Pipeline industrial rate" is the average price of natural gas sold to industry after transportation by pipeline. See Surrtr-WuraERLY REP. 407. This rate is slightly higher than the average total industrial rate, see note 128 supra, because pipeline consumption excludes that third of total industrial consumption sold for field use and carbon black manufacturing, Syith-Wimberly Rep. 360 Table 2, at very low prices. Id. at 364, Table 4 (field use); id. at 366 , Table 15 (carbon black).

135. The average soft coal price to large industrial users was $\$ 4.19$ per ton in 1940 and $\$$ \$̧.28 per ton in 1947. Surte-WrMrerLy REP. 344 n.5. For conversion standard see note 128 supra.

136. Id. at 338, Table 16. For conversion standard see note 128 supra.

137. See Natural Gas-IWhoosh!, Fortune, Dec. 1949, p. 107, 114 et seq.; Address by Hudson Reed, President, Am. Gas Ass'n, to Nat. Gas Spring Conference, Azr. Gas Ass'z, Nat. Gas Dep't, Proceedings 1, 2 (1948); Hearirgs, supra note 3, at 249.

138. Hearings, supra note 2 , at 360 , Figure 2.

139. Id. at 203.

140. See Sartth-Winrberly Rep. 187. Declining field prices up to World War II are attributed largely to supply outrunning demand. Id. at 183.

141. See chart, Natural Gas Reserves in United States v. Net Production, SintrWIJrBERLY REP., facing 45.

142. Id. at 183-4. 
depend on the judgment of individual geologists. ${ }^{143}$ This may lead buyers and sellers, in arriving at their price decisions, to avoid consideration of the speculative supply side of the picture and concentrate on the reality of an insistent increasing demand. A second explanation may lie in the fact that in large measure the estimates of recent years represent upward revisions of earlier guesses on the capacity of known fields rather than primary discoveries of new fields. ${ }^{144}$ An increase in the estimated gas reserve of a known field might not have the price-depressing effect of a similar volume of gas discovered in hitherto virgin territory. A new primary discovery confronts sellers with the horrifying prospect that vast reserves may be opened up in areas much closer to markets than theirs.

A third explanation for rising field prices may be that the big independent producers today are no longer in such a hurry to sell their gas to pipelines. They are better able than small producers to find other uses for gas in the absence of a satisfactory price from the pipelines. ${ }^{145}$ An increasing volume of casinghead gas, for example, is being pumped back into oil reservoirs. ${ }^{140}$ Moreover, some producers have stated that gas is being held off the market for fear that its sale would bring a greater part of the producer's business within the FPC's reach if the Commission moves against the independents. ${ }^{21 t}$

An additional if not alternative explanation for rising field prices in the face of increased supply may be the existence of monopoly pressures in the producing end of the industry.

\section{Monopoly elements}

Adequate analysis of monopoly factors behind rising field prices must await the collection of more extensive data. Known conditions, however, suggest possible monopolistic pressures and point to the need for further study.

Independents' affiliations with pipelines. The FPC's list of leading independent producers includes such oil and gas names as Phillips, Chicago, Abercrombie, Shamrock, Huber, Rogers Lacy, Humble, Skelly, and Sinclair.48 The Commission apparently considers as an "independent" producer one who is not an interstate pipeline himself and who is not, as regards a sale to a particlilar interstate pipeline, affiliated with the buyer. ${ }^{140}$ Under this definition the

143. Id. at $41-4$.

144. See Am. Gas Ass'n \& Am. Petrol. Inst., Reports on Proved Resenves of Crude Oil, Natural Gas Liquids, and Natural Gas 20, Table 3 (Dec. 31, 1949).

145. See Duff, Texas Natural Gas, OIL \& GAS J. 81, 82 (Oct. 28, 1948); SMrrir-WrmBERLY REP. 188.

146. See note 25 supra; SMrth-Wimberly REP. 88.

147. See, for example, testimony of Hayden Herd, attorney for an independent, Hcarings, supra note 2 , at $107,110,112-13$; and of $R$. G. Lawton, vice president of McAlester Fuel Co., id. at 169-72; Hearings, supra note 3, at 21. Former Commissioner Olds doubted that gas was being held back for fear of regulation. Id. at 303-9.

148. Hearings, supra note 2, at 17, Table 11, 18-19, Table 14.

149. See, e.g., id. at 207 (explanation of former Commissioner Olds). 
status of a producer and hence his susceptibility to regulation depends in each case on his relationship with his buyer. The Commission uses the term "independent", however, as though it denoted a fixed status. ${ }^{150}$ This makes no difference when the term is applied to producers like Humble and Sinclair, for example, who apparently do not sell gas to any affiliated interstate pipelines. ${ }^{161}$ But the label "independent" is apt to be misleading when applied to a producer like Cities Service Oil Co. which sells gas both to non-affiliated interstate pipelines and to its parent Cities Service, also an interstate pipeline. ${ }^{152}$ The oil company's sales to non-affiliates have so far gone unregulated, and the buyers are apparently being allowed this contract price as an operating expense. ${ }^{103}$ Yet despite the fact that it calls Cities Service Oil Co. an "independent"10 the FPC, in setting rates for the parent pipeline, includes in its rate base some property of the producing company. ${ }^{155}$

Occasionally the FPC has used the Kerr bill's definition of an "independent": a producer who is neither himself an interstate pipeline nor affiliated with one. ${ }^{150}$ A strict application of this definition would, however, remove from the Com-

150. See, e.g., id. at 17, Table 11 (label "independent producers" used in list); id. at 212 (former Commissioner Olds speaks of regulating "independent producers" as a group).

151. It is almost impossible to determine from public records whether such sales are made or not A check of Moody's, Industrials and Standard \& Poor, Conr. DesCRIptions reveals no such sales. And during hearings on the Kerr bill and similar proposals, neither Humble nor Sinclair was charged with making any.

At any rate the FPC has not tried to assert jurisdiction over the sales of these companies to interstate pipelines. Phillips' status, however, is currently in doubt. See note 97 stupra.

152. Cities Service Oil Co. is listed by the FPC as an "independent" producer. Hearinrgs, supra note 2, at 17, Table 11. And the FPC distinguishes between the oil company's sales to "interstate pipelines" in general and its sales to its affiliated interstate pipeline, the Cities Service Gas Co. Id. at 19, Table 15; id., n.2.

153. A check of FPC reports, Moody's, Industrinls, and Standand \& Poor, Corr. Descriptions, does not reveal FPC regulation of such sales made by Cities Service Oil Co.

154. Hearings, supra note 2 , at 17 , Table 11.

155. In Matter of Cities Service Gas Co., 3 F.P.C. 459, 480-2 (1943).

156. The final version of the Kerr bill passed by Congress did not use the term "independent producer" but exempted from FPC jurisdiction "arm's length sales" to interstate pipelines by "a producer . . . not otherwise engaged in and not controlled by or controlling a person otherwise engaged in the transportation or sale of natural gas for resale in interstate commerce." The bill then provided that a sale should be deemed to be made at arm's length if the producer-seller were not affiliated with the buyer. S. 1498, 81st Cong., $2 \mathrm{~d}$ Sess. 2,3 (1950).

The Senate committee report on the Kerr bill defined the term "independent producer" as one which sells gas "at arm's length in interstate commerce but which is not otherwise a 'natural-gas company,' [interstate pipeline] nor affiliated with nor controlling or controlled by such a natural-gas company. The term 'independent' does not appear in the context of the bill but is used here for descriptive purposes in the interest of clarity and brevity." Sen. Rep. No. 567, 81st Cong., 1st Sess. 6 (1949).

Former Federal Power Commissioner Olds seemed at times to have this definition of "independent producer" in mind. See, e.g., Hearings, supra note 3 , at 202. 
mission's list a number of a number of companies it now calls independents. Humble, for example, is a subsidiary of Standard Oil (N. J.) which controls the Interstate Natural Gas Pipeline ${ }^{157}$ and whose shareholders also own a network of interstate pipelines in the northeast. ${ }^{158}$ Similarly the Sinclair Oil \& Gas Co. ${ }^{159}$ is related through its parent Sinclair Oil Corp. to the Colorado Interstate and Canadian River interstate pipelines. ${ }^{160}$

The greater the number of "independent" producers affiliated with pipelines, the greater the opportunity for them to escape the present FPC regulation of pipeline-producers. They could sell gas to each other's pipelines, contending that the sales were made at arm's length and therefore were not subject to price control. There is no indication that such back-scratching arrangements are presently being made. But even if they were the FPC would have a hard time proving it. ${ }^{101}$

Concentration among independents. Advocates of FPC regulation of independents' sales to interstate pipelines argue that natural gas production is concentrated in the hands of relatively few large companies, mostly the major oil firms. ${ }^{162}$ These advocates maintain that monopoly power exists and that it has been used to force pipelines to pay higher prices for natural gas. ${ }^{103}$

Specific evidence to support this charge is lacking. But the assertion of concentration among the independents is not entirely without merit. In 194.7, for example, some 600 producers sold gas to interstate pipelines in the south-

157. As of December 31, 1948 Standard held 72.41 per cent voting control in Humble, and 53.96 per cent voting control in the Interstate Natural Gas Pipe Line Co. 10 STANDARD \& POOR, CoRp. Descriptions 8206 (Jul. 21, 1949). Interstate is under FPC regulation. Interstate Nat. Gas Co. v. FPC, 331 U.S. 682 (1947).

158. Standard stockholders own the Consolidated Natural Gas Co., which in turn controls five operating systems in Ohio, West Virginia, and New York. Moody's, Punlic UTILITIES 1422-4 (1949).

159. The Sinclair Oil \& Gas Co. is the recent successor in name to the Sinclair-Prairio Oil Co., 10 Standard \& Poor, Corp. Descriptions 8270 (Jul. 21, 1949), referred to by the FPC as an independent producer. Hearings, supra note 2, at 17, Table 11.

160. Sinclair Oil Corp. has a 100 per cent interest in Sinclair Oil \& Gas Co., 10 STANDARD \& POOR, CORP. Descriptions 8269 (Jul. 21, 1949), and a 51 per cent interest in the Southwestern Development Co., ibid, which in turn holds a 100 per cent interest in the Canadian River Gas Co., and a 42.5 per cent interest in Colorado Interstate Gas Co. Moody's, Public Utizities 281 (1949). Both Canadian River and Colorado Interstato are under FPC regulation. Colorado Interstate Gas Co. v. FPC, 324 U.S. 581 (1945).

161. Suppose, for example that pipeline-producer $A$ contracts to sell a large volume of gas to pipeline-producer B. Later A contracts to buy another large volume from B. This need not mean collusion. It could mean that when $A$ contracted to sell it had more than enough gas to meet its own needs, and that subsequently, facing an unexpected increase in demand, A does have to bny gas to replace what it previously sold.

162. See, e.g., 96 ConG. Rec. 3782-7 (Mar. 21, 1950) (Sen. Douglas); Hcarings, supra note 2, at 382-5 (former Commissioner Olds).

163. See, e.g., ibid.; 96 Cong. Rec. 3787, 3788, 3790 (Mar. 21, 1950); id. at 3837 (Mar. 22, 1950). 
western area. ${ }^{164}$ Thirty-five companies made 72 per cent of these sales, ${ }^{105}$ amounting to about 44 per cent of the pipelines' total requirements. ${ }^{16 s}$ As compared with the degree of concentration in the coal industry, ${ }^{107}$ for example, these figures tend to indicate the existence of monopoly power. ${ }^{103}$ But compared with the concentration in the steel industry, ${ }^{109}$ the presence of 35 big gas producers, and hundreds of small ones, looks like thriving competition.

There is no evidence that concentration among independent gas producers is likely to increase. The meager evidence available indicates simply that they will hold their own. Twenty-six of the southwest's big independent sellers to interstate pipelines in 1947 are expected by this FPC to appear again among the 35 leaders in 1952.170 These 35 producers will furnish, according to the FPC, 71 per cent of the pipelines' purchases ${ }^{171}$ instead of the 72 per cent supplied in 1947.

Profits of the independents. Another earmark of monopoly power is a

164. Supplesnental Hearings, supra note 7, at 365 . About 41 interstate pipelines were then operating in the southwest. Hearings, supra note 2, at 206.

The government reported 7,782 companies engaged in oil and gas production in 1939. U. S. Dep't Comar., Statistical Abstract of the United States 776 (1949). In 1946 an independent stated that "there are approximately 20,000 such individuals and companies" engaged in oil and gas production. Hearings before Special Committee Ineestigating $P_{c}$ troleum Resources Pursuant to S. Res. 36, 79th Cong., 2d Sess. 67 (1946).

About 2,300 producers were selling to the country's 114 interstate pipelines in 1947. Supplemental Hearings, supra note 7, at 365 (producers); FPC, Statistics of Nat. GAS Courpanies v (1947) (pipelines).

165. The FPC lists sales by the 36 largest producers to interstate pipelines in the southwest in 1947. Their aggregate sales were 733,988,922,000 cubic feet. Hearings, supro note 2 , at 18-19, Table 14. To compare the leaders' share of the market in that year with their share in 1952, for which only 35 producers are listed, see note 171 infro, the $6,099,459,000$ cubic feet sold in 1947 by Sunray Oil Co., the thirty-sixth ranking producer, were deducted from the leaders' totals. This leaves $727,899,463,000$ cubic feet sold by the first 35 producers, or 72 per cent of the $1,012,504,187,000$ cubic feet bought by interstate pipelines in the southwest in 1947. Id. at 16, Table 8.

166. The 35 leading producers supplied $727,899,463,000$ cubic feet, see note 165 supro, out of a total of $1,639,527,202,000$ cubic feet bought and produced in the area by interstate pipelines. Id. at 16 , Table 8 .

167. For a brief description of competition in the bituminous coal industry see Wrrcox, Cosipetition and Monopoly in Ayrerican Industry 24-26 (TNEC Monograph No. 21, 1940).

168. See Edwards, Matntaining Competrion 93 (1949).

169. United States Steel Corp. has maintained over 30 per cent of national steel ingot capacity and production for 47 years. See Hearings before Subcommillec on Study of Monopoly Power of House Committee on Judiciary, Slst Cong., 2d Sess. Pt. 4B, 5, Exhibit S-6 (1950). In 1947 eleven companies had over 90 per cent of national steel production capacity. Id. at 682, Exhibit S-327.

170. Hearings, supra note 2 , at $18-19$, Table 15.

171. The 35 leading sellers will supply an estimated $1,671,110,000,000$ cubic feet in 1952. Id. at 19, Table 15. Interstate pipelines accounting for 96.5 per cent of the total interstate take in the southwest are expected to buy $2,325,548,000,000$ cubic feet from independents in that year. Id. at 16, Table 10 . 
continuing record of excessive profits. ${ }^{172}$ In charging the independents with monopoly, critics have pointed accusingly at high profits. ${ }^{173}$ Former Federal Power Commissioner Olds, for example, has presented figures showing the "income available for common stocks as per cent of common stock and surplus" of 21 big independents for the years 1946 through 1948. For 1946 these figures ranged from 5.7 to 19.3 per cent; for 1947 , from 11.9 to 28.9 per cent; and for 1948 , from 16.3 to 41.8 per cent. ${ }^{174}$ Assuming the accuracy of these figures, ${ }^{175}$ their significance is open to question on at least two counts.

In the first place, most independents produce both oil and gas. How much of their profits were derived from the sale of gas and how much from the sale of oil, the price of which doubled between the start of 1946 and the end of 1948 ? 170 The separation of oil and gas earnings requires an allocation of costs for which a satisfactory method has not yet been devised. ${ }^{177}$

Second, even assuming that the independents were making excessive profits on their gas sales, do excessive profits for a two- or three-year period necessarily indicate monopoly power? The existence of excessive profits over an extended

172. See Boulding, Economic Analysis 537 (1941).

173. See, for example, the remarks of Sen. Douglas of Illinois, 96 Cong. Rec. 3772-3; 3786-7 (Mar. 21, 1950); of Rep. Crosser of Ohio, id. at A2651 (Apr. 4, 1950); and of former Federal Power Commissioner Olds, Hearings, supra note 3, at 220.

174. Id. at 232. Olds referred to these figures during the House hearings, id. at 220, and also brought them to the attention of the Senate. Hearings, supro note 2, at 366. Rep. Crosser of Ohio had them incorporated in 96 CoNG. REc. A2651 (Apr. 4, 1950).

175. The table listing these figures carried the notation that 1948 earnings were "estimated based on data reported by Moody's Financial Service." See Hearings, supra note 2, at 366 , Table 4. A spot check of some of these figures was made for 1946 and 1947, using MOody's, Industrials. The net income for each year was computed as a per cent of the common stock and surplus at the close of the previous year. The following discrepancies with $\mathrm{Mr}$. Olds' figures appeared:

Plymouth Oil Co.

\begin{tabular}{cc}
\multicolumn{2}{c}{ Olds' figures } \\
$(1946)$ & $(1947)$ \\
17.6 & 28.7 \\
18.6 & 26.0 \\
18.5 & 28.9 \\
6.6 & 27.0
\end{tabular}

\begin{tabular}{cc}
\multicolumn{2}{c}{ Spot check } \\
$(1946)$ & $(1947)$ \\
18.3 & 34.8 \\
21.1 & 31.7 \\
20.6 & 33.9 \\
20.0 & 69.3
\end{tabular}

Shamrock Oil \& Gas Co.

Warren Petroleum Corp.

6.6

26.0

28.9

69.3

176. In January, 1940, the Kansas-Oklahoma well price of oil was $\$ 1.11$ per barrcl. Survey of Current Business S-33 (U.S. Dept. Comm. Mar. 1946). In October 1946 this price was $\$ 2.51$. Id., S-36 (Dec. 1948).

177. Natural gas is usually found in the search for the more valuable oil. At one time a gas well was regarded as little better than a dry hole, its cost to be charged to oil revenues. If now the gas is sold, is the revenue pure profit? Similarly, if a well produces both gas and oil, is the cost of the well to be charged only to oil? It is apparently accepted practice in the oil industry to deduct gas revenues from the cost of producing oil. See U. S. TARIFF Comin'n for OPA, Crude Petroleum 43 (1942).

At present, where a pipeline producer extracts natural gasoline and nuisances from its natural gas, the FPC includes the cost of the extraction plant in the rate base and uses the revenue from natural gasoline to offset expenses. Cities Service Gas Co. v. FPC, 155 F.2d 694 (10th Cir. 1946), cert. denied, 329 U.S. 774 (1946). The independents fear the FPC 
period would presumably afford such an indication: otherwise newcomers would enter the field for a share of those earnings. But where production has failed to keep up with a spurt in demand, profits for an individual firm or for an industry as a whole may be temporarily high without indicating a lack of competition. $^{178}$ In each year since the close of World War II most industries have reported record profits. ${ }^{179}$

Since no close study has been made of gas producers' profits, it is impossible to say whether they point to monopoly or not.

\section{Interfuel competition}

\section{Checks on Field Prices}

As the prices of coal and oil have climbed, the gas producers have grumbled that the gas they are selling is under-priced. They want the price of gas to rise to reflect its "intrinsic value" as a fuel; in other words, to bring all the traffic will bear in competition with coal and oil. 180

If this policy were followed, it would seem at first that field prices could rise until they had pushed end rates so high that unhappy customers switched to coal and oil. This might be the case with the bulk of industrial consumption,

would do the same thing with their oil business if it regulated their gas sales: trest their oil activities as an offshoot of gas production. The independents might then be furnishing gas free of charge. See Hearings, supra note 2, at 119-20, 144, 161, 242-3, 416-17.

The FPC says it would not go this far. It would attribute part of the investment in an oil-gas well to gas production and leave the company's oil revenues alone. See id. at 241-3, 416-17; Supp. Hearings, supra note 7, at 318. Some of the states have faced this problem. E.g., Re United Fuel Gas Co., P.U.R. 1918C, 193, 206 (W.Va. 1918). So far the FPC has not. The FPC has had, however, the similar problem of allocating pipeline transmission costs as between regulated (interstate utility) and non-regulated (intrastate and direct industrial sales). In Colo. Interstate Gas Co. v. FPC, 324 U.S. 581 (1945) the Court approved an FPC allocation, including a return on investment, that covered both phases of the problem. The Court pointed out that the Natural Gas Act does not require insistence on any particular formula. Id. at 589.

Wherever the FPC drew the line, the independents would not want to sell gas to pipelines if they could make more money by extracting natural gasoline or making synthetic fuel.

Many of the new contracts between independents and the pipelines stipulate that the producer can back out if the FPC tries to regulate him. Supp. Hearings, supra note 7, at 353-9. If the FPC did step in it probably would need an injunction to prevent abandonment of service. Public necessity might compel the granting of such an injunction. And if the independent were later found to be a "natural gas company" under the Natural Gas Act, he would have to stick by his original contract to supply gas. See Hcarings, sufpro note 2 , at 220,224 . But suppose the pipeline wants more gas. Would the producer have to meet this new demand? Why should the producer be compelled to furnish natural gas to the pipeline at a lower price than he could get by selling his gas for another use?

178. See Boulding, Economic Analysis 601-2 (1941).

179. See 34 Fed. Res. Bull. 842 (1948); Survey of Current Busmess 7-S (U.S. Dept. Comm. Dec. 1948); Corporate Profits, Another New Record, Business Weel; Feb. 5, 1949, p. 74.

180. See pp. 1501-2 infra. 
where natural gas competes chiefly on price terms with coal and oil. At recent price levels, industrial gas sales could bear a whopping increase. ${ }^{181}$ But rates for the "convenience" uses of natural gas-those of domestic, commercial and certain industrial consumers-would meet a check quite apart from out-and-out competition from coal and oil. This ceiling would be the rates at which "convenience" users would switch to manufactured gas or electricity. It is extremely difficult to measure just when such a ceiling might be reached. Former Federal Power Commissioner Olds has charged that a rise in gas rates to the level of comparative oil prices in 1947 would have added $\$ 506$ million to the $\$ 834$ million gas bill of utility customers. ${ }^{182}$ It is impossible to answer this charge because the accuracy of the figures cannot be checked: Mr. Olds did not announce how he made his calculations. ${ }^{183}$

The present price relationship among various fuels concededly encourages rising field prices for natural gas. But opposed to higher field prices is the adverse interest of the pipelines. Unregulated on their "direct" industrial sales, ${ }^{184}$ they want to increase their own profits by beating down the field price at which they buy gas. ${ }^{185}$ Conceivably, the pipelines' self-interest in this respect might be counter-balanced by the fact that they buy large volumes of gas for sale to utilities. ${ }^{186}$ Since this sale rate is a "cost plus" figure, ${ }^{187}$ the pipelines might

181. In August, 1950 the wholesale price of mine run bituminous coal was $\$ 8.70$ per ton; the wholesale price of No. 2 distillate fuel (oil) in New York harbor was 8.2 cents per gallon. Survey of Current Business S. 35-6 (U. S. Dep't Comm., Oct. 1950). This coal price is equivalent in heat units to a natural gas rate of about 33 cents; the oil price to a gas rate of about 60 cents. See Saritr-Wimberly Rep. 347, Table 21.

182. Hearings, supra note 2 , at 364 , Table 1 . Several times during the hearings $\mathbf{M r}$. Olds referred to this table. See, for example, $i d$. at $233,288$.

183. Domestic and commercial rates for natural gas were markedly higher than comparative oil prices in 1947; direct industrial gas rates were far lower. If Mr. Olds simply recast industrial gas rates in terms of oil prices, his statement is misleading because it ignores the big share of the market where gas does not compete on purely price terms with oil. Moreover, it is not clear why Mr. Olds chose to use only comparative oil prices. A calculation in terms of the corresponding coal price in 1947 would lower the possible natural gas rise; an estimation in terms of comparative manufactured gas rates would push the natural gas rise higher. See note 127 supra.

184. The Federal Power Commission is barred from regulating the interstate pipclincs' rates for direct industrial sales by the Natural Gas Act, which gives the Commission jurisdiction only over "sales . . . for resale." 52 STAT. 821, \$1(b) (1938), as amended, 15 U.S.C. $\$ 717$ (b) (1946).

So far the states have not attempted to fix these direct industrial sales prices. But state jurisdiction over such sales was upheld in Panhandle Eastern Pipe Line Co. v. Pub. Service Comm'n of Ind., 332 U.S. 507 (1947). On this precedent the Supreme Court of Michigan recently upheld its Commission's decision that Panhandle must obtain a certificate of convenience and necessity for its direct industrial sales. N. Y. Times, Oct. 14, 1950, p. 22 , col. 2.

185. Cf. SMITH-WimberLy REp. 216 n.39.

186. See note 17 supra.

187. "Cost plus" in the sense that under present FPC regulation the pipelines charge their gas purchases as operating expenses to be recouped in sales rates. Sce note 79 supra. 
not care how much they paid for their gas. There are three reasons, however, why this is not so.188 In the first place, the pipelines have no desire to see fieid prices rise to a point where they start to reduce the "convenience" demand for natural gas. ${ }^{189}$ Second, although the pipelines under present regulation can expect to recover in full whatever price they pay in the field to independents, this recovery is not automatic. It takes a rate proceeding that may drag on for several years. ${ }^{190}$ And finally, the producers sell their gas to the pipelines at a flat price per thousand cubic feet, with no discrimination according to the ultimate use of the gas.191 Thus although the "convenience" uses might support a higher field price than industrial consumption, ${ }^{102}$ a rise in field prices that pushed "convenience" rates too high might price the producers right out of the industrial market. The lower of the end rate limits-whether "convenience" or industrial193 — would therefore tend to become the ceiling for both.

\section{Competition among producers}

The essence of competition among sellers is the availability to buyers of alternatives in the market. In the natural gas industry this choice may lie between different fields and between producers in the same field. Advocates of FPC regulation of independents' prices contend that the pipelines' freedom of choice is virtually as restricted as that of the household consumer, because both are physically tied to their suppliers. ${ }^{194}$ This analogy is not very accurate. The

Presumably the FPC has the power to prevent "improvident" payments for raw materials. BARNES, op. cit. supra note 52, at 606 . But the question is what payment is "improvident" when field prices are not regulated and there is no recognized "market price"

188. Whatever their reasons, the pipelines' opposition to increased field prices is cridenced by their fight against the minimum price fixing actions of Kansas and Ol.lahoma. See note 217 infra.

189. In the present period of insatiable demand for natural gas this point would not be reached quickly. See pp. 1484, 1487-9 supra.

190. For example, the proceedings in the Colorado Interstate case were begun March 14, 1939. After extensive hearings the FPC rendered a decision 3 arch 18, 1942. In Mfatter of Colo. Interstate Gas Co., 3 F.P.C. 32, 35 (1942). The Supreme Court affirmed the FPC decision April 2, 1945. Colo. Interstate Gas Co. v. FPC, 324 U.S. 581 (1945).

191. Conceivably the independents might try to sell their gas as do the pipelines and distributing companies, at prices that vary according to the class of user. But for the utilities this price differential is not discrimination; it is justified by the different costs of supplying, for example, a large volume of gas to a single buyer and the same volume to thousands of buyers.

192. The field price of natural gas in the southwest in 1947 represented about 8 per cent of the average domestic-commercial rate and 27 per cent of the average industrial rate. [Field price 4.65 cents, Hearings, supra note 2, at 18; domestic-commercial rate 59 cents; and industrial rate 17 cents. See p. 1489 stpra].

193. But low-priced industrial sales may give way gradually to higher-priced sales with the development of storage facilities near markets. See note 130 supro.

194. See, for example, the remarks of Sen. Douglas of Illinois, 96 Co:ic. REc. 3658, 3685 (Mar. 20, 1950), id. at 3769 (Mar. 21, 1950); of Sen. Meyers of Pennsylvania, id. at 3534 (Mar. 16, 1950); of Rep. Sullivan of Nebraska, id. at A2796-7 (Apr. 4, 1950). 
small consumer has no practical choice between distributing companies because he is not prepared to build his own line to connect with them. Interstate pipelines, however, are prepared within limits to do just this to reach suppliers.

Interfield competition. Initially, a pipe line can plan to reach gas supplies in fields scattered across a half dozen states. ${ }^{105}$ Before the pipeline is built its promoters can seek acreage or contracts and then map their route on the outcome of this dickering. ${ }^{108}$ Two of the big postwar pipelines, for example, start deep in Texas and come north along the Gulf coast through Louisiana, passing more than a dozen fields. ${ }^{107}$ The older pipelines in the southwest, most of which hold gas acreage themselves, usually tap two or more fields in the gas belt stretching from southwestern Kansas to Louisiana. ${ }^{108}$

Nevertheless, once a pipeline has been laid, competition among suppliers is narrowed to the fields along its route. Since a pipeline cannot be shifted around like a hose, producers in the hooked-up fields probably could boost prices substantially before the pipeline threatened to extend to other fields. And producers in these other fields, already connected to pipelines, need strong incentives to launch feeder lines so that they can compete with producers some distance away.

Intrafield competition. Within the gas fields, sales competition among producers is fostered by the fact that pipelines are always ready to hook up with new suppliers. Nevertheless price competition among producers is sluggish because field prices do not respond rapidly to changes in supply and demand. Unlike wheat or even oil, for example, natural gas is not sold from day to day at "spot" prices, but on the basis of long term contracts that fix prices far in advance. ${ }^{100}$

The liveliness of the bargaining on these contracts depends in part on the effect of state regulation of production. In theory at least, prorationing restricts competition among producers by limiting the amount each can take from his wells. ${ }^{200}$ Since each producer knows that his neighbors are thus held back, his hand is strengthened in dealing with the pipelines. This tends to bolster prices. $^{201}$ In practice, however, state prorationing may not restrict competition

195. See map, Major Producing Areas in the United States, SArtur-WmderLY REP, facing 40 .

196. See, e.g., an account of the dickering by Texas Illinois Natural Gas Pipeline Co. 10 Standard \& Poor, Corp. Descriptions 7949 (Aug.-Sept. 1949).

197. See routes of Tennessee Gas Transmission Co. and Trans-Continental Gas Pipe Line Corp., Hearings, supra note 2, map facing 360. Trans-Continental will start delivery this year. Moody, Public Utilities 1580 (1949).

198. Panhandle Eastern, Northern Natural, Colorado Interstate, and Citics Service, for example, all tap the Hugoton and Panhandle fields. United Gas Pipe Line draws gas from many smaller scattered fields. See SMITH-WIMrERLY REP., map facing 242.

199. See id. at 213, 219. Many contracts have "escalator" clauses calling for price increases every few years, see p. 1487 supra, but these increases are set in advance at the time the contract is signed.

200. See p. 1473 sipra.

201. The price-bolstering effect of prorationing has been discussed chiefly in connection with oil. "Various excuses for restricting output are given but certainly the fundamental 
so severely. Production quotas are not frozen: producers can expand their quotas by opening up new acreage. ${ }^{202}$

Moreover, the states provide a positive spur to competition among producers in laws forbidding the blowing of casinghead gas into the air. These laws force producers either to dump their gas on the market immediately, at any price they can get, or to pump it back into the ground where it becomes a reserve that hangs over the market in the future. ${ }^{203}$

Yet competition among producers in a field clashes head on with the growing desire to extract oil and gas efficiently. Gradually competition has given ground to cooperation. The best example of this is when oil and gas fields are operated as units in the manner that engineers agree gives optimum recovery.

Restrictions on entry into production. An important check on rising prices is not only competition among concerns presently engaged in production, but also the possibility of entry into the field by new firms. ${ }^{203}$ No data are available that would indicate the ease or difficulty of entry into the gas production business. Most of the present leading independent producers have long been big companies. ${ }^{206}$ On the other hand some of today's big independents, like

purpose is to eliminate competition that prices may be raised" KessNITzER, REDIRTI of Monopoly 97 (1938). See Watrins, Oil: Stabilizatron or Conservation? 120-38 (1937). This writer concludes that conservation is incidental to price stabilization. Id. at 255.

202. Since a producer's individual quota depends largely on the acreage and number of wells he has, see note 41 and text sipra, he can expand his quota to a larger share of the pool quota by adding acreage and wells.

203. See p. 1490 stpra; SxItTH-WrarberLy Rep. 188.

204. For a discussion of unitization see p. 1474 sipro. The idea behind unit operation of a pool is to have surface owners ignore, for operating purposes, their zigzagging surface boundaries and produce oil or gas as could an individual who owned the entire pool. Production can then be tuned perfectly to buyers' demands. This necessarily eliminates competition in production among participants in the unit. In theory it need not climinate price competition among them. Each participant could receive his share of production and sell it on his own. But the essence of price competition among sellers is the buyers' freedom to choose among them. A buyer has little choice in filling his demand when he is faced by individual sellers whose offered volumes are so fixed that in the aggregate they equal his dernand. The buyer must take the individual shares offered or go without. He cannot reject one seller and take a larger volume from another. In practice, then, there would be little incentive for sellers to engage in price competition.

From the standpoint of competition not only the production of the oil or gas but also its marketing might just as well be carried on by the unit operator. Because it is simpler to split up the sales proceeds among the unit participants than to hand them shares of the product, this unit marketing procedure is usually followed. See, for example, Arcaslin, Nation's Largest Unit Operation Accomplishes Mfuch in First Three Jlonths, OIL \& GAs J. 44,63 (Jan. 1, 1948).

205. See Edwards, Míatntaining Couspetition c. 6 (1949).

206. For a list of the leaders, see Hcarings, supra note 2, at 18, Table 14.

In 1947 Phillips Petroleum Co., for example, was the leading seller of gas to interstate pipelines in the southwest, with sales of 116 billion cubic feet, ibid, out of total independents' 
Chicago and Republic, are comparative newcomers to the top ranks. ${ }^{207}$

Nevertheless, increasing costs of exploration ${ }^{208}$ may be limiting entry into a field that has traditionally been wide open for the individual or small firm with nerve and money to gamble. When the lone wolf strikes oil or gas, he often sells his property to an established company which then carries on the production and marketing. ${ }^{208}$

Summary. Various kinds of competition impose some limits on field prices, but these limits are probably not low enough to prevent a considerable price increase.

\section{Government Regulation of Field Prices}

The economic justification for government interference with field prices for natural gas is that competition is falling down on the job. The simple fact of rising prices is not enough, per se, to support the conclusion that competition has failed. If competition has failed, however, rising prices may mean that producers are making excessive profits at the expense of consumers. To prevent such exploitation the federal or state governments might appropriately intervene in the natural gas industry.

The government might act in one of three ways. First, the federal government might take over the industry and produce and market gas itself. Second, it might take steps, through antitrust suits or administrative regulation, to restore competition among producers. ${ }^{210}$ Neither nationalization nor the restoration of competition is being seriously considered today. But the third step-direct price control by the federal or by state governments-is a real possibility.

sales of one trillion cubic feet. Id. at 16, Table 8. Phillips' assets in that year were about $\$ 439$ million. Phillips Petroleum Company, Annual Report 5 (1949). At the same time Humble Oil \& Refining Co. made the fourth largest volume of sales to interstate pipelines in the southwest.

In 1933 Phillips had total sales of 189 billion cubic feet (sales to interstate pipelines not reported), and assets of $\$ 179$ million. Moody, Industrials 2363 (1934). Humble had assets of $\$ 249$ million (no report of its gas sales). Id. at 2950 .

207. In 1947 the Chicago Corp. and the Republic Natural Gas Co., for example, made the second and third largest volumes of sales, respectively, to interstate pipelines in the southwest. Hearings, supra note 2, at 18, Table 14.

In 1933 Chicago was not in the gas business. Starting as an investment trust in 1929, it had assets of $\$ 24$ million in 1933, MOODY, BANks 643 (1934), and entered the oil and gas business in 1941 with the acquisition of reserves in Texas. Moodx, Banks 1313 (1948). Republic started in the oil and gas business under another name in 1928, and in 1933 was adjudicated bankrupt. MOODY, INDusTrials 2868 (1934).

208. See SMITH-WIMBERLY Rep. 188.

209. See Hearings before Sen. Spec. Committee Investigating Pctrolcum Resources Pursuant to S. Res. 36, 79th Cong., 2d Sess. 33 (1946).

210. See pp. 1497-1500 supra.

The establishment of effective inter-pool competition would require first, the development of an extensive system of lines making it possible for each pipeline to draw gas from more fields, and second, probably the abandonment of long-term contracts in favor of "spot" 


\section{State regulation}

So far the producing states, far from worrying about producers' high prices and profits, have been interested only in putting a floor under field prices for natural gas. Producers in recent years have complained loudly that prices are too $10 w^{211}$-that increases are needed both to compensate them for the "intrinsic value" of natural gas ${ }^{212}$ and to encourage conservation and exploration. ${ }^{213}$ Legislators in Texas and Louisiana ${ }^{214}$ have listened and responded by

pricing that would permit the flow of gas from different fields to vary in response to fluctuations in supply and demand.

The transportation phase of inter-pool competition might be met in cither of two vays. On the one hand the existing pipelines could extend branches into each of the various fields. This would require, however, an enormous investment in additional duplicating lines which the consumer would pay for in higher rates. On the other hand the fields could be connected by common carrier pipelines. A glance at a pipeline map gives the impression that this could easily be achieved. The various fields are now fairly well tied together physically by a network of pipes. See map in Hearirgs, supra note 2, facing 360 . These interincing pipes are not now common carriers, but separate integrated gas systems serving their own customers in the southwest. The problems that would arise in making common carriers of gas pipelines are formidable. See Connor and Biddison, Common Carrier Obligations as Applied to Natural Gas Transmission Lines, Asr. Gas Ass'r, Nat. Gas Dep'r, ProceedINGS 66 (1935).

The achievement of "spot" pricing in the gas fields would put pipelines to bidding against each other for their immediate needs on a day-to-day or month-to-month basis. Field prices and perhaps end rates, indirectly, would fluctuate accordingly. See discussion of fuel adjustment clauses, note 56 supra. Consumers would then regard themselves as the beneficiaries (if rates went down) or victims (if rates went up) of a flexible price system that would do the job cut out for competition: the allocation of resources, in terms of supply and demand, to those whose want and buying power is greatest. This price allocation is imperfect today because field prices are either frozen under long-term contracts or, if subject to "most-favored nation clauses", see note 122 supra, can go up but cannot come down.

"Spot" pricing in the gas fields might, however, have an undesirable effect on service to consumers. It works well enough in the oil market, perhaps because oil can be stored in tanks in the field and at the refinery end of the pipelines, and thus can flow in more or less irregular shipments. If a gas pipeline did not know from one day to the next where its supply was coming from, its service might become an interruptible one, with its attendant inconvenience and hazards as well. See note 225 infra.

Long-term contracts on the other hand assure a steady supply of gas. This is why the FPC requires such contracts before it authorizes construction of pipelines. See Hearings, supra note 2 , at $161,179,183$. But a steady supply of gas at the intake end of the pipeline might be unnecessary if enough storage facilities were available at the consuming end. See note 130 supra.

211. See, for example, Starmont, Minimum Gas Prices, OIL \& Gas J. 38 (Jan. 12, 1950); Surite-Wimberly Rep. 190; Hearings before House Commillec ols Interslatc Commerce on H. R. 2185, 2235, 2292, 2569, and 2956, 80th Cong., 1st Sess. 353 (1947).

212. By "intrinsic value" the gas producers mean a price per heat unit equivalent to that of coal or oil. See Draper-Olds Rer. 139.

213. See SyItTH-Wimrberly Rep. 190-1; Draper-Ords Rep. 118.

214. Aar. Bar Ass'n Sec. of Minn. Law, Conservation of Orl asid Gas-A Legat History 456 n.19 (1948) (Texas, 1947); id. at 236-7 (Louisiana, 1946, 1948). 
introducing bills authorizing the fixing of minimum prices in the field. The regulatory commissions of Oklahoma and Kansas, also hearing these complaints, have fixed minimum prices even without explicit stattutory authority. 210 And these orders have been upheld by the respective state supreme courts. ${ }^{210}$

It takes little imagination to see that regulation by the producing states offer's slim hopes for containing field prices. If the producers are strong enough to convince their legislators, commissions, and courts to shore up prices that are already climbing rapidly, they could easily block attempts to impose state price ceilings. Apparently the voice of local consumers counts for little in the producing states. And certainly the voice of millions of consumers in other states counts for nought.

Moreover, state price regulation may not be legal. The Kansas and Oklahoma price fixing orders may be an unconstitutional burden on interstate commerce when applied to sales to interstate pipelines. ${ }^{217}$ And the Supreme Court may find that the federal government, through the Natural Gas Act, has preempted the field. 218

\section{Federal regulation}

Only the federal government could reasonably be expected to clamp down on natural gas field prices to prevent producers from reaping excessive profits at the expense of consumers. But such action should not be taken until several basic questions are answered with respect to price fixing methods and the effect of price control on the conservation of natural gas.

Price fixing methods. If the chief aim of federal regulation of independents' prices is to prevent excessive profits, the initial problem is the twofold one of measuring profits and then determining when they are excessive. So far this dual problem has been given scant consideration. ${ }^{210}$ Moreover, once the

215. Peerless Oil \& Gas Co. v. Cities Service Gas Co., Okla. Corp. Comm'n Order No. 19514 (Dec. 9, 1946) ; In re Hugoton Gas Field, 77 P.U.R. (N.S.) 150 (Kan. 1949). The Oklahoma Commission set a minimum price of 7 cents per thousand cubic feet on natural gas sales in its part of the great Hugoton field that stretches across the Oklahoma panhandle into Kansas and Texas. Kansas went Oklahoma one better by setting a minimum price of 8 cents per thousand cubic feet in its part of the Hugoton field. A few months before the Kansas order was issued, three interstate pipelines were buying gas in the Kansas Hugoton field at average prices of $43 / 8,4.6$ and 5.5 cents per thousand cubic feet. Brief for Appellants 16, 21, 20, Kansas-Nebraska Nat. Gas Co. v. State Corp. Comm'n, 222 P.2d 704 (Kan. 1950).

216. Cities Service v. Peerless Oil \& Gas Co., 220 P.2d 279 (Okl. 1950) ; Kansas-Nebraska Nat. Gas Co. v. State Corp. Comm'n, 222 P.2d 704 (Kan. 1950).

217. The pipelines argued this point in the State courts. Cities Service v. Pecrless Oil \& Gas Co., supra note 218, at 291 ; Brief for Appellants 96-103, Kansas-Nebraska Nat. Gas Co. v. State Corp. Comm'n, 222 P.2d 704 (Kan. 1950). But the supreme courts of Oklahoma and Kansas rejected this attack with scant discussion.

218. See Interstate Natural Gas Co. v. FPC, 331 U.S. 682 (1947), rchcaring denicd, 332 U.S. 785. (1947). And see discussion p. 1481 stipra.

219. See pp. 1493-5 sipra. 
measurement problem has been solved there are two radically different approaches to the separate problem of fixing prices. One approach aims at the result theoretically achieved by competition: the elimination of above normal profits by the producing industry as a whole. The other approach is that of public utility regulation: control of the profits of individual firms.

Under the industry-wide approach, the federal government presumably would undertake to set uniform maximum prices at which independents could sell to interstate pipelines. These uniform prices might vary among broad regions. But they would be set only as high as necessary to bring forth the desired volume of gas. ${ }^{220}$

How would such uniform prices be arrived at? The only feasible method is to rely on past experience in the industry. ${ }^{221}$ That experience, as shown by the government's chief price-fixing experiments to date, is largely the story of cost. $^{222}$ In a new experiment with regulating field prices, the government might, for example, set maximum prices by tacking a mark-up on the average

220. See Mr. Justice Jackson, dissenting in FPC v. Hope Nat. Gas Co., 320 U.S. 591, 652-3 (1943). The present Natural Gas Act requires only that rates for a natural gas company be "just and reasonable" 52 Stat. 822 (1938) as amended, 15 U.S.C. $\$ 717$ c (1946). While the FPC has in practice set pipeline rates on an individual company basis, the Act would not seem to prohibit the Commission, if it undertook to regulate field prices, from establishing uniform prices. See id. at 652 .

221. Conceivably a rate fixing body might throw past experience to the winds, pull rates out of a hat, and simply wait to see how they affect the industry tomorrow. The Hope case, 320 U.S. 591 (1943), might be read to allow this trial and error "method" at least as applied to prices for individual firms. The gist of the Hope majority opinion was that FPC rates for a particular company would be reasonable if under such rates the company remained healthy. Id. at 602-3.

Yet it is hard to imagine that any commission would adopt a technique of price fixing that could be validated only by hindsight. Since producers would complain loudly at any price cut, the commission would have a hard time deciding just how low a price would in fact be ruinous. Too low a guess might drive firms out of business and disrupt production before the commission discovered its error.

Moreover the constitutionality of such a rate method would be wide open to attack on the ground that rates so fixed were arbitrary and confiscatory. This objection might even prevail against uniform rates, based on experience in the industry, which would deprive some producers of a fair return. See note 224 and text infra.

222. During the depression of the 'thirties the federal government undertook to fix minimum prices for milk and bituminous coal. There were no definite standards for setting milk prices, but past prices and costs played an important role. Factors considered were historical prices, prices for manufacturing purposes, transportation and sanitation costs, market prices, and the notion of a "fair" price. See WaLLACE, Ecosiosic Starddards of Governarent Price Control 85-7 (TNEC Monograph No. 32, 1941). Alinimum coal prices were supposed to be set equal to the average weighted cost per ton in the price aren. See id. at 274 et seq.

World War I maximum coal prices were set on a cost-plus basis. See id. at 247. And during World War II, OPA ceiling prices for bituminous cosl, oil, and textiles were based largely on costs. Harris, Price and Retated Controls in tue United States 51 (1945). 
cost of production in an area. The chief difficulty in working with costs on an industry-wide basis, however, is that it takes a tremendous amount of time to assemble the necessary data. When minimum prices were attempted in the coal industry, it took three years to get the cost facts. ${ }^{223}$

Under uniform price fixing on an industry-wide basis, low-cost producers would prosper and high-cost producers presumably would be driven out. 224 For producers to drift in and out of the market at will might curtail the continuous flow of gas that is the essence of service to consumers. ${ }^{225}$ On the other hand, forcing individual producers to continue service when they were losing

223. See WALLACE, op. cit. supra note 222, at 313 .

224. This seems to be the suggestion of Mr. Justice Jackson, dissenting in FPC v. Hope Nat. Gas Co., 320 U.S. 591, 652 (1943).

The constitutional objection to maximum prices under which some individual producers may not make a profit is that such action deprives them of their property without due process of law. This objection has been dismissed where the price fixing complained of was carried on under the war power. Bowles v. Willingham, 321 U.S. 503, 518 (1944).

But the due process objection has not yet been squarely dealt with where maximum prices have been fixed on the basis of governmental authority outside the war power. The most recent federal case dealing with this problem is Jordan v. American Eagle Firc Ins. Co., 169 F.2d 281 (App. D.C. 1948). There several fire insurance companies objected that the uniform maximum rates fixed by the District of Columbia were confiscatory becauso they denied certain companies a fair profit. The Court of Appeals sent the case back to the trial court for more specific findings on this point. Without deciding the constitutional issue, the Court reviewed at length the cases relied on to sustain maximum prices which would deprive some firms of a profit.

The authority for the constitutionality of such price fixing is nccessarily meager, bccause the precise issue has not yet arisen. But dicta and analogy argue persuasively in favor of constitutionality.

Under minimum price fixing a firm may be caught between the competitively determined price at which it sells and the fixed cost (minimum price) at which it buys. An objection by a business in this plight was rejected in Fegeman Farms Corporation v. Baldwin, 293 U.S. 163, 170 (1934). Mr. Justice Brandeis distinguished minimum from maximum prices, $i d$. at 171 , in a manner that seems to imply that firms thus squeczed by maximum prices could complain. But there is no sound reason for finding constitutional significance in the fact that a maximum price order affects one person's selling price while another affects his costs. In either case he may suffer loss. Sce Freund, The Eurcrgcucy Price Control Act of 1942: Constitutional Issues, 9 LAw \& Contemp. Pron. 77, 83-4 (1942).

See Bowles v. Willingham, 321 U.S. 503, 518 (1944) (rent control); Aetna Ins. Co. v. Hyde, 275 U.S. 440, 447 (1928) (insurance rates); Brass v. North Dakota, 153 U.S. 3!1, 401, 410 (1894) (grain elevator rates) ; Tagg Bros. \& Moorhead v. United States, 29 F.2d 750, 755 (D.Neb. 1928), aff'd 280 U.S. 420 (1930) (stockyard brokers' rates). Sec also Freund, supra, at 83-4; Note, 34 CoL. L. REv. 1336, 1339-40 (1934).

But see Aetna Ins. Co. v. Hyde, supra, at 446; Matthew Addy Co. v. United States, 264 U.S. 239 (1924) (World War I coal prices).

225. It is usual pipeline practice to meet peak demands, see p. 1488 supra, by packing the line under full pressure so that for short periods gas may be withdrawn from the line faster than it goes in. See Smith-Wrmberdy Rep. 274. The "accordion" effect of this line storage allows a flexibility of input. See Potter, The Effect of Pipe Line Storage and Operation of Sources of Supply on Transmission Line Capacities During High Dcmand Pcri- 
money at the ceiling price would certainly be unfair and very probably would be unconstitutional ${ }^{226}$ as well.227

In contrast to the industry-wide approach to price control is the method of public utility regulation, which concerns itself with the profits of individual firms. The FPC uses this approach in regulating pipelines, allowing them as profits a return on the net investment-actual legitimate cost less depreciation and depletion-in their property. ${ }^{228}$ Congressmen, independents and the FPC have assumed, without discussing alternatives, that this same method would be applied to the independents' prices if the FPC undertakes to control them. $=0$

In its pipeline regulation the FPC has concentrated chiefly on whether the company's books show expenditures actually made. The independents would oppose this emphasis on actual investment with understandable vehemence. It would probably catch many of them as it did the pipelines: currently receiving prices much higher than a "fair return" on the cost of property acquired years before. ${ }^{230}$

The industry argues that this net investment procedure achieves unjust results. ${ }^{231}$ Producer $A$, who spends $\$ 10,000$ and hits gas on his first drilling, re-

ods, Asr. Gas Ass'n, Nat. Gas Dep'r, Proceednos 74, 82 (1938). Nevertheless input does follow, whether smoothly or unevenly, variations in demand. Id. at $80-1$, Figs. 5,6 .

If producers could supply gas or not as they chose the correspondence between input and output would be purely fortuitous, leaving consumers to face a potential collapse in service at the time they need it most. Moreover, a cutoff of input that dropped gas pressure suddenly would not only deprive distant householders of hot water and warmth. It might snuff out a burner tip flame, with the danger that when pressure vas restored the gas would flow into the house through an open valve.

These hazards might be avoided by having large storage facilities near markets, from which gas could be drawn in event of temporary interruptions at the field end of the pipelines. See note 130 supra.

226. See note 224 supra.

227. Somewhere in limbo between the industry-svide maximum and the individual-firm approaches to price control is the price freeze. Its use is justified chiefly in time of emergency, for lack of time to prepare a better scheme, or as the initial step in a longer-range program. See HARris, op. cit. supra note 222, at 56; Dickerson, The "Frecse" MTelhod of Establishing Ceiling Prices, in Franck and Quint (ED.), Proplews m Pruce Controu: Pricing Technigues 31-72 (Historical Rep's on War Administration: Office of OPA, Gen. Pub. No. 8, 1947).

As a permanent price fixing technique the "freeze" would do just that to inequities already existing among producers and consumers, eliminating neither the excessive profits of the industry as a whole nor those of a particular firm.

228. See pp. 1478-9 sipra.

229. See, e.g., Hearings, supra note 2, at 95 (Sen. Kerr) ; id. at 505-6 (Independent Petroleum Ass'n of America); id. at 10 (FPC report on Kerr bill).

230. See Colo. Interstate Gas Co. v. FPC, 324 U.S. 581, 610-11 (1945) (47,000 acres included in rate base at $\$ 4,244.24)$; Cities Service Gas Co. v. FPC, 155 F.2d 694, 706-7 (10th Cir. 1946) (68,000 acres included in rate base at zero), cert. denied, 329 U.S. 773 (1946).

231. See Hearings, supra note 2, at 152; Surte-Wnrbercy REp. 210, 217-18. The industry has been joined in this view by Mr. Justice Jackson. FPC v. Hope Nat. Gas Co.. 
ceives a 6 per cent return on his rate base of $\$ 10,000$. But Producer $B$, who drills several dry holes and spends $\$ 50,000$ before striking gas, perhaps in the same pool, receives a 6 per cent return on his $\$ 50,000$. This rewards individuals for their efforts instead of their achievements. The pipeline-producers who have had experience with the cost rate base tried to remedy this economic injustice first by returning to the discredited "fair value" rate base. ${ }^{232}$ Failing in this, they sought to compel the FPC to exclude their producing property from the rate base and allow them the "average field price" for their gas as an operating expense. ${ }^{233}$ This proposal was also unacceptable to Congress.

But the Supreme Court has opened the door to avoidance of the FPC's cost rate base by allowing interstate pipelines to sell their producing property. The FPC included in the rate base of Panhandle Eastern Pipe Line at its actual cost of $\$ 955,000$ gas acreage which the company claimed was worth $\$ 8,400,000.234$ Panhandle then set up the Hugoton Production Co. with a capitalization of $\$ 10,000,000$ and turned over to it $\$ 675,000$ and 97,000 acres recently included in Panhandle's rate base at $\$ 160,000$. In return Panhandle took an option to buy gas from this acreage after 1964, and all of Hugoton's stock. The stock was then distributed to Panhandle's shareholders. Hugoton aims to transmit and sell gas in Kansas, ${ }^{235}$ which uses "fair value" regulation. ${ }^{230}$ "Presumably Kansas will now allow Panhandle's investors a fair return on the "fair value" of property which under the FPC would have earned a return only on its cost.

After a pipeline has sold its producing property it may later buy gas, to meet its own requirements, at a field price higher than the allowance it would have received on its own production. Consumers would foot the difference.

In the past the FPC has not scrutinized carefully the propriety of particular expenditures; rather it has been satisfied that expenditures actually were

320 U.S. 591, 649 (dissenting) (1943) ; Colo. Interstate Gas Co. v. FPC, 324 U.S. 581, 610 (1944) (concurring).

232. See Colo. Interstate Gas Co. v. FPC, 324 U.S. 581 (1944); Panhandle Eastern Pipe Line Co. v. FPC, 324 U.S. 635, 648 and n.8 (1944).

233. See, e.g., Hearings, supra note 2, at 456 (Panhandle Eastern Pipe Line $C_{0}$.); id. at 467 (Union Producing Co., an affiliate of United Gas Pipe Line Co.). Such a "market price" or "value" allowance was one of the chief aims of the pre-Kerr bill proposals to amend the Natural Gas Act. See note 85 supra.

The obvious defect of this proposal is the danger of price rigging. Since the pipelines are the chief outlet for producers, the prices they pay largely determine the average field prices. Allowing them the average field price for their own production would encourage them to increase their return by raising the prices paid to independents. Sce SMIru-WinBERLY REP. 223-5. There seems little safeguard against this in the proposal of Federal Power Commissioners Smith and Wimberly that the pipelines' production allowance be based on the "weighted average" of contract prices in the field. Id. at 235.

234. Panhandle Eastern Pipe Line Co. v. FPC, 324 U.S. 635, 648 and n.8 (1944).

235. FPC v. Panhandle Eastern Pipe Line Co., 337 U.S. 498, 500-1, 519-20 (1947).

236. FPC, op. cit. supra note 51 , at 8 , Table B. 
made. ${ }^{237}$ Since this assures recovery of virtually all costs, ${ }^{235}$ the high-cost prospector turns out to be a fortunate fellow whose mistakes are rewarded by the rate subsidies of the consumers. This might tempt an independent producer to spend money for the purpose of enlarging his rate base. .39

Interstate pipeline-producers are continuing to add to their producing acreage despite greatly increased purchase costs. ${ }^{240}$ With today's enormous demand for natural gas it may be difficult for the FPC to determine whether a given expenditure for producing acreage is a reflection of its current market value or attempt by the purchaser to increase the net investment rate base on which he receives his return.

In the face of attempts by pipeline-producers to inflate their rate bases, the FPC would probably begin to insist that expenditures be "legitimate" as well as "actual." The objection that this would interfere with the prerogatives of management might be easily brushed aside.2\$1 But the Commission could not

237. E.g., Isz IIatter of Colorado Interstate Gas Co., 3 F.P.C. 32, 43 P.U.R. (N.S.) 205, 215 (1942) (write-up of acreage on its transfer from one affiliate to another), offirmcd, Colorado Interstate Gas Co. v. FPC, 324 U.S. 581 (1944).

238. See SMrTh-W IMrgerLy REP. 198-201. Nevertheless independents persisted in complaining, throughout Congressional consideration of the Kerr bill and its predecessors, that the FPC does not allow capitalization of unsuccessful exploration and drilling. E.g., Hearings, supra note 2, at 120-1, 128-9. This was flatly contradicted by the FPC. E.g., id. at 325 .

239. See Surth-Wiarberly Rep. 208-9. The only clear limitations on thus enlarging the rate base would be the amount of money the company could scrape up, and its fear of spending too much for acreage where the chance of finding gas is highly speculative. Yet if made in good faith even a sour investment should under FPC regulation be redeemed by consumers.

240. Hearings, supra note 2 , at 316,320 .

An example of the high prices currently being paid for producing property by interstate pipelines is a recent purchase by the El Paso Natural Gas Co. Early in 1949 El Paso, planning a new line from the southwest to California, contracted to buy a large volume of gas from the Delhi Oil Corp. The contract gave Delhi the right to ancel if it were brought under FPC control. 96 Cowg. Rec. 3658 (Mar. 20, 1950). The FPC ruled that under its Order No. 139, stpra note 86 , this sale would not subject Delhi to its jurisdiction. FPC Rules No Jutrisdiction in Delhi Gas Sale Proposal, On. \& GsS J. 201 (Alar. 17, 1949). Later, in a letter to Sen. Hayden of Arizona, the FPC indieated that Delhi might come under its jurisdiction. When Delhi cancelled its contract with El Paso the pipeline contracted to buy gas rights in the necessary acreage. 96 Covg. REc. 3658-9 (Mar. 20, 1950). Under this contract El Paso acquired gas rights on $13,6 \$ 0$ acres for $\$ 3$ million plus an overriding royalty of 5 to 7 cents per thousand cubic feet of treated gas. Delhi reserved the oil rights in the land. Dellii Sells Holdings, Ors \& GAS J. 164 (Jan. 26, 1950).

Presumably EI Paso will receive a return on the $\$ 3$ million in its rate base, and will also be allowed as operating expenses the royalties paid to Delhi. Compare this with the earlier situations in the cases cited note 230 supra.

241. When state commissions have attempted to disallow certain operating expenses as "improper" utilities have argued that this is an interference with management's rights. This objection has been circumvented by the theory that commissions are not actually forbidding the challenged operating expenses. The commissions are simply exercising their accounting control in not allowing utilities to record certain outlays as operating expenses. 
treat lightly the practical difficulties of determing what expenditures are "legitimate." While the FPC may be able to keep its eye on the cost of building giant pipelines here and there, it would not be so easy to watch the cost of buying up and drilling cow pastures all over Texas. ${ }^{242}$ If the FPC's cost method is extended to include the independents, these difficulties will increase.

Conservation and allocation. Any program for fixing maximum field prices may thwart the long-range conservation of natural gas. Limiting field prices would probably call for a corresponding check in end rates to consumers, with the result of sustaining demand. But is it desirable to encourage the rapid exploitation of the country's gas reserves ?243 During the last generation oil and gas have furnished a growing share of the country's energy requirements at the expense of coal. ${ }^{244}$ Yet gas reserves are running roughly a scant 30 years ahead of production; oil reserves, about 12. Coal deposits, on the other hand, will last several thousand years. ${ }^{245}$

With these facts the following dismal picture has been painted: The steady piping of gas all over the country will drain the southwest of a fuel resource needed to encourage the development of industry in that region. ${ }^{240}$ The increasing use of gas and oil may wreck the coal industry and perhaps cripple the railroads which count heavily on coal for freight. When gas and oil peter out the coal industry will have to be revived. Perhaps twice in a lifetime there will be great social distress following the shift from one fuel supply to another. ${ }^{247}$

These gloomy prospects have turned FPC and Congressional hearings into battlegrounds for various pressure groups seeking or opposing federal action. ${ }^{248}$

See BARNEs, op. cit. supra note 52, at 605 . A similar rationale would support disallowance of amounts originally spent in acquiring property. See also the discussion of over-investment in unoperated oil acreage in Re United Fuel Gas Co., 1918C P.U.R. 193, 208-9 (1918).

242. See SMith-WimberLy REP. 209.

243. For pessimistic views of the effects of unrestricted exploitation of gas reserves see Blachly \& Oatman, Natural Gas and the Public Interest c. 9 (1947); DraterOlds REP. 27-115. A more optimistic view is expressed in Rostow, A NatronaL Policy FOR THE OIL INDUSTRY 31-33 (1948).

244. In 1920 coal supplied 75 per cent of the nation's energy, oil about 15 per cent, and natural gas about 5. By 1946 the respective contributions were approximately 45,30 and 15 per cent. Smith-Wramberiy Rep. 315, chart 2. And by 1949 coal's share of entergy consumption was down to 38.5 per cent. Bureau of Mines estimate, N.Y. Times, Mar. 8, 1950 , p. 29, col. 4 .

245. SMITh-WIMBERIy REP. 307 (estimates in 1946).

246. See Draper-Olds Rep. 33-49, 61-74.

247. See Blachlx \& Oaturan, op. cit. supra note 243, at 122-5; SMitir-WinderrLY REP. 300-2.

248. The Natural Gas Act of 1938 required interstate pipelines to obtain certificates of public convenience and necessity from the FPC for expanding their service only when a pipeline proposed to enter a market already served by another pipeline. 52 STAT. 821, §7(c) (1938). This prevented the FPC from considering the economic effects of natural gas displacement of coal markets and railroad freight. See H. REP. No. 1290, 77th Cong., 1st Sess. 2-3 (1941). In 1942 the Act was amended to give the FPC jurisdiction over all interstate pipeline facilities. The Commission could determine the service area in which a 
The crisis that would follow the exhaustion of natural gas may be avoided without further government intervention in the industry. While oil and gas reserves are limited at any one date, the increase in reserves has so far outstripped demand. And there is no reason to suppose that the end is yet in sight. Future discoveries, however, can merely postpone the exhaustion of reserves; they will not avoid it. The long-range answer to the fuel problem lies in attaclis on the cost of mining coal, ${ }^{249}$ of synthesizing gas and oil from coal, ${ }^{200}$ of recovering oil from shale, ${ }^{251}$ and extracting liquid fuel from peat. ${ }^{252}$ And around

pipeline was to operate and the pipeline could expand its facilities within such area without further authorization. 56 STAT. 83, $\$ 7$ (c), (f) (1942), 15 U.S.C. $\$ 717 c$, f (1946).

Though requested to determine service areas for the pipelines, the FPC continued to conduct hearings on each proposed extension of facilities. In these hearings the railrozds and coal companies, as well as labor unions in both fields, have been allowed to intervene in opposition to natural gas expansion. See Hearings before House Commillec on Interstate Conmerce on H. R. 2185, 2235, 2292, 2569, and 2956, 80th Cong., 1st Sess. 211-262 (1947).

The problem of natural gas competition with other fuels was the subject of an FPC investigation in 1945-6. See note 8 supra. The results of the study appeared in two separate reports. Commissioners Smith and Wimberly expressed no views about the wisdom of unrestricted fuel competition. See Surte-Wrarberly Rer. 351-9. They did, however, recommend certain amendments of the Natural Gas Act to expedite action on pipeline applications for service extensions. See id. at 494-5. But Commissioners Draper and Olds based their report on the thesis that natural gas is an irreplaceable resource whose unlimited export from the southwest will hinder the economic development of that region. DRAPER-OLdS REPORT 61-74. They advocated FPC consideration of the end use to which natural gas may be put in granting certificates to pipelines. Id. at 12-13.

The Rizley bill of 1947, see supra note 85, would have allowed pipelines to extend service in existing markets without obtaining permission from the FPC, and would also have barred the Commission from restricting the type of end use of gas. Hearings, silpra, at 3. This was supported by pipelines, $i d$. at 211 , by independent producers, id. at $126,155-7$, 512 , by some local distributing companies, id. at 298-300, and also by communities and industrial users who wanted more gas. See letters printed id. at 517-31. On the other hand the Rizley measure was opposed by many distributing companies fearing the competition of pipeline sales made direct to industry, id. at 536-8, and by communities which feared expansion of gas service would curtail their supply, id. at 516, 519. Also opposing the bill were the railroads, id. at 484-505, and railway workers, id. at 509-10. The cosl interests introduced a bill of their own that would have declared a fuel policy allowing the FPC to protect their markets. H.R. 2569, 80th Cong., 1st Sess. (1947).

249. There are two phases to this attack. One is the development of new mining equipment. See Contintuots Coal Mfining, Fortune, June 1950, p. 11. The other is the development of underground gasification of coal : burning coal in the ground and drawing off the gas. See Engel, Coal Without Shozels, 170 Nation 202 (1950); Skrotzhi, Undergrourd Gasification Goes on Second Trial at Gorgos, Power, April 1949, p. 79.

250. The cost of conversion is now the only reason for using oil and gas in thcir natural state. A brief account of the technical and economic aspects of malling gas from coal is found in SMITH-WIMBEERIY REP. 445-64.

251. See Roberts and Schuitz, Production of Liquid Fucls from Oil Shalc, Orz \& GaS J. 16 (Sept. 15, 1949).

252. Peat reserves may exceed those of coal. See Linz, Liquid Fucl From Pcal, Orc \& GAS J. 47 (April 6, 1950). 
the corner, at an uncertain distance, lies the commercial development of atomic energy.

However long natural gas resources may last, FPC control of field prices would affect the allocation of supplies. Some people have argued, for instance, that field prices should be held down to provide cheap fuel for encouraging industrial development in the southwest..253 But a flat cut in field prices would give outside industries a "free ride," too. Other people have therefore urged that field prices be kept up or even be boosted to discourage cheap industrial consumption outside the producing states. ${ }^{254}$ But this action would also discourage industrial consumption in the southwest. These conflicting aims could be reconciled by adopting discriminatory prices-low for southwest consumption, higher for outside use. ${ }^{255}$ Such a price differential would find producers reluctant to sell in the southwest. To overcome their reluctance the government might have to subsidize southwestern sales or boost rates for other areas high enough to force those areas out of the market.

\section{CONCLUSION}

Solution of the problem of rising field prices of natural gas demands a thorough investigation to light many dark corners. The causes of the price phenomenon must be sought out. Possible monopoly elements should be uncovered. Competitive forces which tend to limit prices need to be appraised and balanced against price lifting pressures. Should investigation disclose that normal market forces will not keep prices within reason and prevent monopoly profits, government regulation should be undertaken. This regulation would inevitably affect the rate and character of natural gas consumption. Whether field prices should be manipulated deliberately to alter consumption patterns and whether Congress or the FPC should make this decision are further questions to be determined.

On the basis of present knowledge FPC regulation of independents' prices would be imprudent. It would also be an extension of authority into an area where Congress has never deliberately considered, let alone sanctioned regulation. Should the FPC attempt field price regulation without a legislative mandate, Congress should block the move.

253. Draper-Olds Rep. 150-2, 157 .

254. Cf. BLACHLy AND OATMAN, op. cit. supra note 243 , at 38-40, 146, 158-9.

255. At least this is a theoretical possibility. To put it into operation might require an amendment of the Natural Gas Act, which now forbids natural gas companies to "main" tain any unreasonable difference in rates . . . either as between localities or as between classes of service." 52 Stat. 822, $\$ 4$ (1938) as amended, 15 U.S.C. $\$ 717 \mathrm{c}$ (1946). Whether an amendment would be necessary depends on the interpretation of "tunreasonable." Present price differentials between classes of service (domestic as against industrial, for example) are not per se "unreasonable." This might also be true of a price differential based on a policy of promoting regional development. 